\title{
New Cricetodontini from the middle Miocene of Europe: an example of mosaic evolution
}

\author{
PALOMA LÓPEZ-GuerRero, M. ÁNgeles ÁlVAREZ-SIERRA, ISRAEL GARCÍA-PAREDES \& \\ PABLO PELÁEZ-CAMPOMANES
}

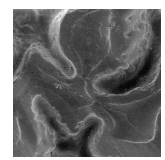

\begin{abstract}
A new species of Cricetodontini (Cricetidae, Rodentia, Mammalia), Cricetodon nievei sp. nov. from the Toril section (Toril 3A, Toril 3B, Toril 2) and Las Planas 5H is described. All this sites belong to the local biozone G3 (late Aragonian, late middle Miocene) from the Calatayud-Daroca Basin (Zaragoza, Spain). The new species displays a mosaic pattern consisting in a combination of primitive and derived characters: the upper molars have a basal Cricetodon-like pattern short and not complete ectolophs -, whereas the lower molars share several derived features with the older representatives of Hispanomys - absence of metalophulid II. The generic assignation of the new taxon is further discussed and it is compared with all the species of Cricetodon and Hispanomys described until date. This mosaic evolutionary pattern of dental characters is also recognized in other species of Cricetodontini from Europe during the late Aragonian, although involving different combination of morphological characters. At this time, the diversity of the tribe increases, including species with complex morphology and higher intraspecific variability than the older representatives. The new species proposed here is morphologically close to Cricetodontini recorded outside the Calatayud-Daroca Basin, especially C. albanensis and H. decedens from France. Finally, the palaeoecological context of the new species is discussed; the stratigraphical distribution of Cricetodon nievei sp. nov. coevals changes in the faunal assemblages which are possibly related to an increase of humidity detected in the Calatayud-Daroca Basin. $\bullet$ Key words: Cricetodon, Hispanomys, mosaic morphology, Calatayud-Daroca Basin, late Aragonian, middle Miocene.
\end{abstract}

LÓPeZ-Guerrero, P., Álvarez-Sierra, M.A., García-PAredes, I. \& PeláeZ-CAmpomanes, P. 2014. New Cricetodontini from the middle Miocene of Europe: an example of mosaic evolution. Bulletin of Geosciences 89(3), 573-592 (6 figures, 5 tables). Czech Geological Survey, Prague. ISSN 1214-1119. Manuscript received August 28, 2013; accepted in revised form January 4, 2014; published online March 19, 2014; issued June 9, 2014.

Paloma López-Guerrero (corresponding author), M. Ángeles Álvarez-Sierra \& Israel García-Paredes, Departamento de Paleontología, Facultad de Ciencias Geológicas, Universidad Complutense de Madrid, C/ José Antonio Novais 2, 28040 Madrid, Spain, and Departamento de Geología Sedimentaria y Cambio Medioambiental, Instituto de Geociencias IGEO (CSIC, UCM), C/ José Antonio Novais 2, 28040 Madrid, Spain; palomalopez@geo.ucm.es, masierra@geo.ucm.es, isgarpa@geo.ucm.es •Pablo Peláez-Campomanes, Departamento de Paleobiología, Museo Nacional de Ciencias Naturales (MNCN, CSIC), C/ José Gutiérrez Abascal 2, 28006 Madrid, Spain; pablopelaez@mncn.csic.es

The tribe Cricetodontini (Rodentia) is commonly present in the European Miocene; it provides relevant information regarding the biochronology, biostratigraphy and palaeoecology of the continental deposits (Van der Meulen \& Daams 1992; Daams et al. 1999a, 1999b; Van der Meulen et al. 2011, 2012). The representatives of Cricetodontini are considered to be immigrants in Asia Minor around the Oligocene-Miocene boundary (De Bruijn \& Ünay 1996). During the early Miocene (Mammal Neogene zones MN1 and MN2, sensu De Bruijn et al. 1992 and Steininger 1999), the tribe remains modest in the number of both species and specimens. The diversification and geographical expansion into continental Europe start later on, at MN5. During the late Aragonian (MN7/8), the tribe reaches its maximum diversity (De Bruijn \& Ünay 1996, Rummel 1999). In the middle Aragonian the species of Cricetodontini display a widely extended geographical distribution; all of them are included in the genus Cricetodon, showing a primitive stage-of-evolution according to De Bruijn \& Ünay (1996).

During the latest part of the middle Miocene (late Aragonian) new combinations of morphological dental characters among the species occur. The intraspecific variability and the diversity seem to be higher than in older assemblages (De Bruijn \& Ünay 1996). The taxa exhibit a mosaic morphology that consists in the development of different rates of change in the jugal teeth. In this interval, the transition from Cricetodon to Hispanomys, in southwestern 


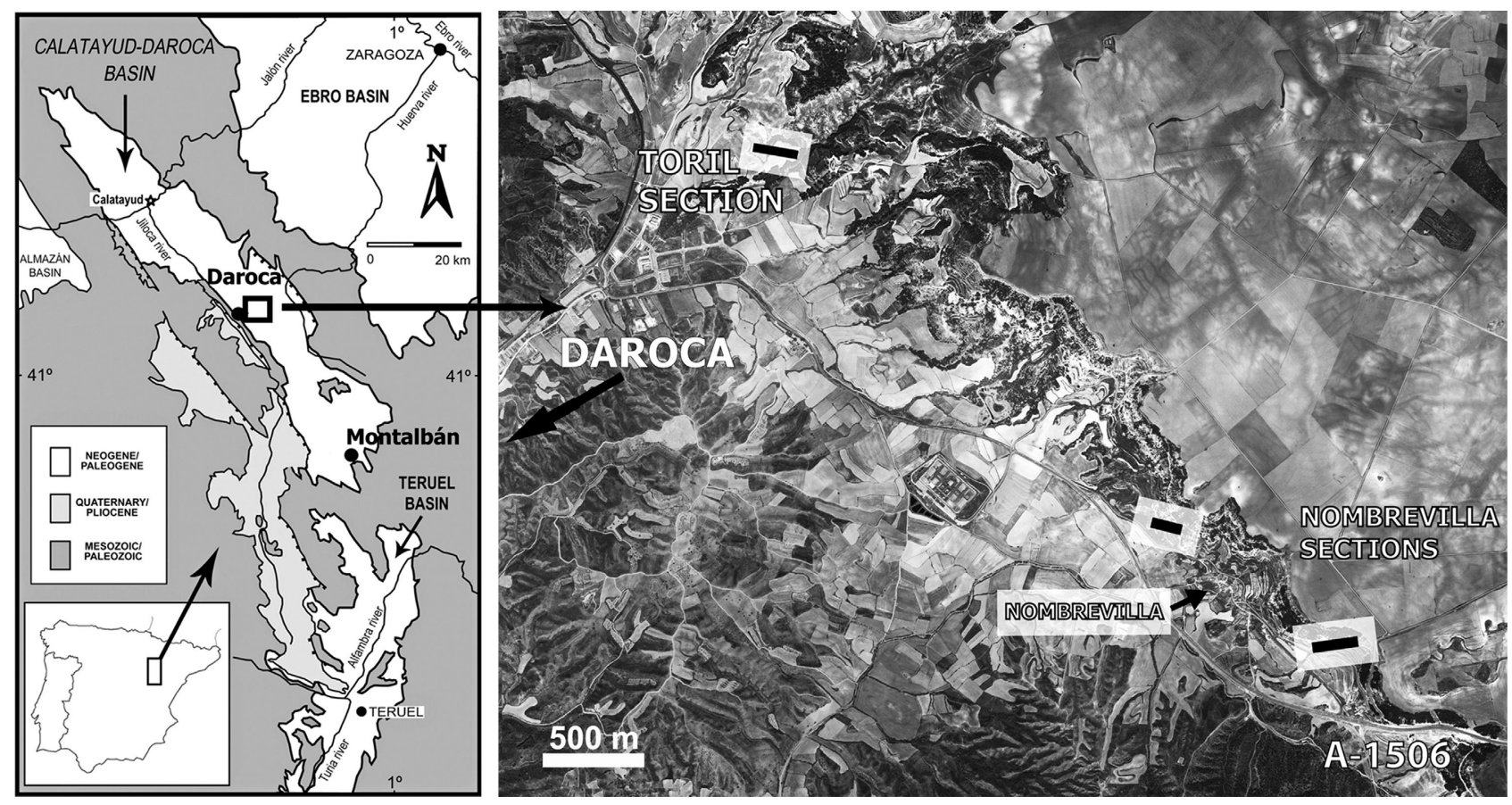

Figure 1. Geological map of the Calatayud-Daroca Basin. The square marks the situation of the area of Daroca (modified after García-Paredes et al. 2010). The orthophotograph shows the position of Toril and Nombrevilla sections.

Europe (Agustí 1980, De Bruijn et al. 1993, Aguilar et al. 1994, López-Guerrero et al. 2008, López-Antoñanzas \& Mein 2009), and to Byzantinia in Turkey (De Bruijn et al. 1993, De Bruijn \& Ünay 1996) took place. Therefore, the evolutionary history of the tribe Cricetodontini gathers important taxonomic changes during the late Aragonian.

In this paper we have studied the fossils of a new species found in the upper Aragonian from the CalatayudDaroca Basin (Daams et al. 1999a, Álvarez-Sierra et al. 2003). The rodent fauna from this basin has been extensively studied by many authors (Daams \& Freudenthal 1981, 1988; Álvarez-Sierra 1987; Daams et al. 1998; Peláez-Campomanes 2001; Van der Meulen et al. 2003; García-Paredes 2006; Oliver et al. 2009; García-Paredes et al. 2009, 2010; López-Guerrero et al. 2013; Oliver \& Peláez-Campomanes 2013). Specifically, our study is part of an ongoing systematic and phylogenetic revision of the Cricetodontini from this basin (López-Guerrero et al. 2008, 2009, 2011, 2013).

The tribe Cricetodontini is represented by six species in the late Aragonian from Calatayud-Daroca Basin (Freudenthal 1966; Mein \& Freudenthal 1971a; LópezGuerrero et al. 2008, 2009): Cricetodon cf. sansaniensis Lartet, 1851, Cricetodon jotae Mein \& Freudenthal, 1971, Hispanomys aguirrei (Sesé Benito, 1977), Hispanomys lavocati (Freudenthal, 1966), Hispanomys nombrevillae (Freudenthal, 1966), and the new species described here. Their stratigraphical distributions, according to the local biozonation proposed by Daams et al. (1999b), are as fol- lows: Cricetodon cf. sansaniensis is present in the local biozone F (Freudenthal 1966); Cricetodon jotae in the G1 (pers. obs.), G2 (Mein \& Freudenthal 1971a) and the early G3 (pers. obs.); Hispanomys aguirrei, Hispanomys lavocati and the new species, in the G3 (Lopez-Guerrero et al. 2008), and finally, Hispanomys nombrevillae is found in the H (López-Guerrero et al. 2009).

Here we describe the new taxon that shows a particular pattern with a combination of basal and derived features. We also compare it in detail with the species of Cricetodontini with close morphology and discuss the context and status with regards to other representatives of the tribe in Europe.

\section{Material and methods}

The studied material includes 274 upper and lower molars. Table 1 contains the number of specimens studied for each fossil site and the abbreviations used. They are housed at the Museo Nacional de Ciencias Naturales-CSIC (Madrid, Spain) and at the Naturalis Biodiversity Center (Leiden, The Netherlands). The studied fossils belong to four localities from the Toril-Nombrevilla section - TOR2, TOR3A, TOR3B - and Las Planas section - LP5H. These sections are located in the Calatayud-Daroca Basin, southern part of the province of Zaragoza (Fig. 1).

All the sites belong to the local biozone G3 from the late Aragonian (Álvarez-Sierra et al. 2003) and they can be correlated to the Mammal Neogene zone MN7/8 (Daams 
Figure 2. Terminology of the parts of the cheek teeth of Cricetodon. Only the M1, M3 and the m1 morphology has been draw; however, this nomenclature can be applied for the rest of the upper and lower molars. Modified after Mein \& Freudenthal (1971b).
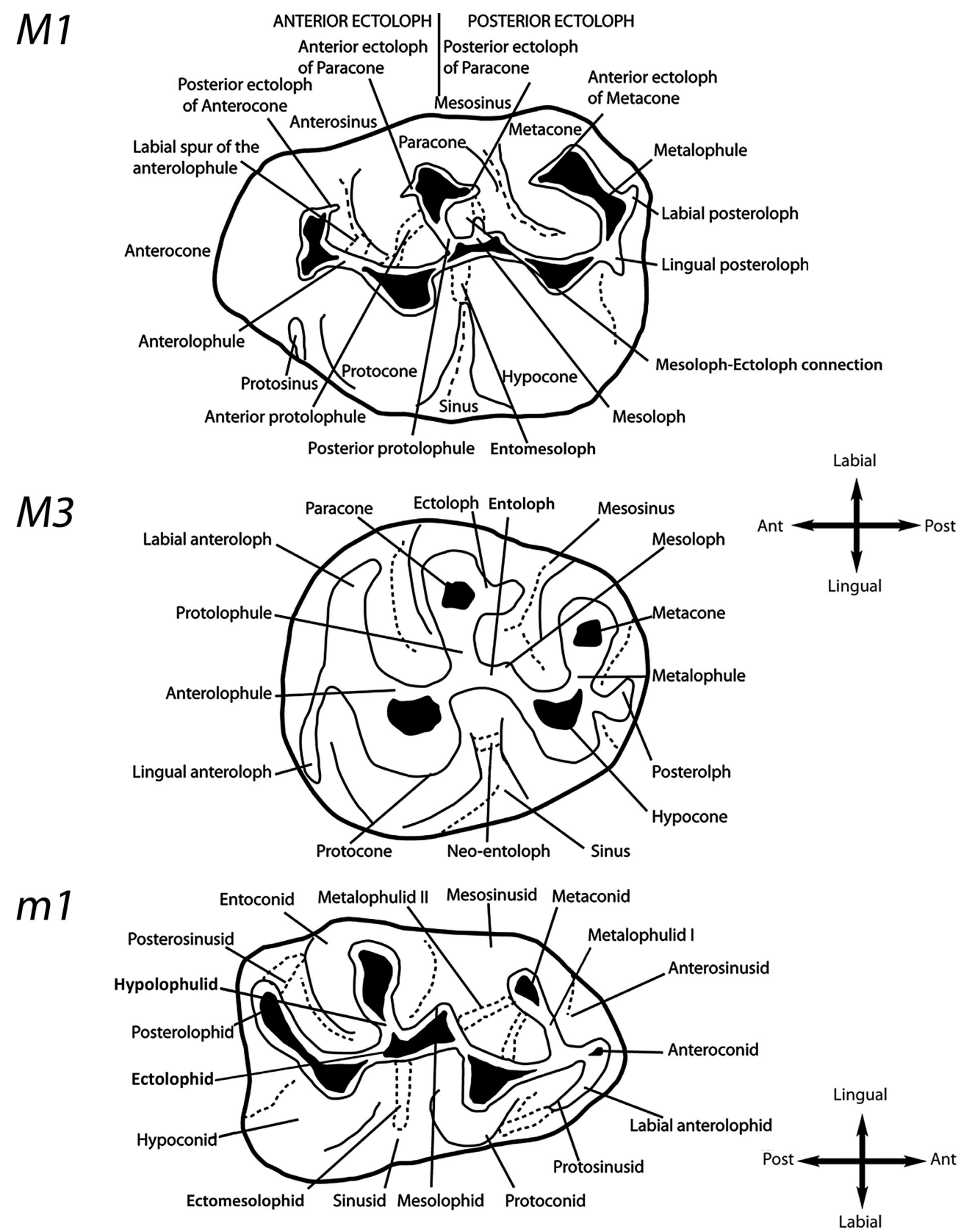

et al. 1999a). The locality LP5H has been correlated to the chron C5Ar.1r (Daams et al. 1999c) that spans a time range of $12.474 \mathrm{Ma}-12.735 \mathrm{Ma}$ (Hilgen et al. 2012). According to Van Dam et al. (2006), the numerical age of LP5H is 12.57 Ma using the local magnetostratigraphical correlation. Additionally, Álvarez-Sierra et al. (2003) and Garcés et al. (2003) correlated LP5H with the localities Toril 2, Toril 3A and Toril 3B.

The new material has been compared with several taxa of Cricetodontini from different localities hosted in other institutions: Cricetodon soriae from the type locality Somosaguas stored at the Universidad Complutense de Madrid (Spain); type material of $C$. bolligeri from Peters- buch 10 and "Cricetodon" fandli from Gratkorn stored at Bayerische Staatssammlung für Paläontologie und Geologie, Munich (Germany); C. sansaniensis from the type locality of Sansan stored at the Muséum d'Histoire Naturelle de Bâle (Switzerland); type material of C. aureus and $C$. meini from Vieux-Collonges, and $C$. albanensis from La Grive-Saint Alban stored at the Naturalis Biodiversity Center (NBC), Leiden (The Netherlands); C. klariankae from the type locality Felsôtárkány-Felnémet stored at Municipal Museum of Pásztó, Pásztó (Hungary), $C$. jotae from its type locality, Manchones, stored at the Instituut voor Aardwetenschappen, Utrecht University (The Netherlands) and finally, the type material of 
Table 1. Material of Cricetodon nievei sp. nov. from the CalatayudDaroca Basin, studied localities, abbreviations for the localities and institutions where the fossils are stored (see institutional abbreviations). $\mathrm{Abb}=$ abbreviations for the localities; $\mathrm{N}=$ number of specimens

\begin{tabular}{lllrrrrrrr}
\hline \multicolumn{1}{c}{ Cricetodon nievei sp. nov. } \\
\hline Locality & Abb & Collection & M1 & M2 & M3 & m1 & m2 & m3 & N \\
\hline Toril 3B & TOR3B MNCN & 8 & 12 & 4 & 10 & 8 & 6 & 48 \\
Toril 3A & TOR3A MNCN & 18 & 30 & 27 & 36 & 24 & 24 & 159 \\
Toril 2 & TOR2 & MNCN & 4 & 5 & 2 & - & 4 & 2 & 17 \\
Las Planas 5HLP5H & RGM & 7 & 9 & 4 & 10 & 8 & 12 & 50 \\
& & Total & 37 & 56 & 37 & 56 & 44 & 44 & 274 \\
\hline
\end{tabular}

Hispanomys aguirrei from Escobosa de Calatañazor stored at the Museo Nacional de Ciencias Naturales, CSIC, Madrid (Spain).

The nomenclature used for the structures present in the occlusal surface, modified after Mein \& Freudenthal (1971b), is summarized in Fig. 2. Notation M1, M2, $\mathrm{M} 3 / \mathrm{m} 1, \mathrm{~m} 2, \mathrm{~m} 3$ is used for upper/lower molars, respectively. Maximum length and maximum width, given in $\mathrm{mm}$, were measured using a Nikon Measuroscope $10 \mathrm{mi}-$ croscope with digital micrometer following LópezGuerrero et al. (2013). Descriptive statistics of measurements are given in Table 2. Length/width scatter-diagrams of $C$. nievei sp. nov. are shown in Figure 3. The scatter-diagrams include $C$. jotae from its type locality, Manchones (Calatayud-Daroca Basin), due to the geographical and temporal proximity, and because of the large sample size, which allows straightforward comparisons with the new species. Among the assemblages of C. nievei sp. nov. size have been compared by performing Levenne's and ANOVA tests in localities with at least five data per dental element (Table 3). Tables 4 and 5 present the measurements of the species of Cricetodon and Hispanomys (type localities) from the late Aragonian used in the discussion chapter. The photographs were taken with an Environmental Scanning Electron Microscope FEI Quanta 200 in environmental mode at the Museo Nacional de Ciencias Naturales-CSIC (Madrid, Spain). Descriptive and analytical statistics have been carried out with IBM SPSS v. 19.0.0 (IBM SPSS 2010). The molars are figured as if they were from the right side; reversed images have been indicated by an underlined label.

Repository institution. - All specimens are housed in the Museo Nacional de Ciencias Naturales-CSIC (Madrid, Spain) with a repository number prefixed by TOR.

Institutional abbreviations. - MNCN, Museo Nacional de Ciencias Naturales-CSIC, Madrid, Spain; RGM, Naturalis Biodiversity Center, former Rijksmuseum van Geologie en Mineralogie, Leiden, The Netherlands.

\section{Systematic palaeontology}

Order Rodentia Bowdich, 1821

Family Cricetidae Fischer von Waldheim, 1817

Subfamily Cricetodontinae Stehlin \& Schaub, 1951

Tribe Cricetodontini Simpson, 1945

\section{Genus Cricetodon Lartet, 1851}

Type species. - Cricetodon sansaniensis Lartet, 1851.

Cricetodon nievei sp. nov.

Figures 4-6, Tables 1-3

1981 Cricetodon from LP5H. - Daams \& Freudenthal, p. 4, fig. 1.

1984 Cricetodon from LP5H. - Daams \& Van der Meulen, p. 246 , fig. 2.

1988 Cricetodon spp. from LP5H. - Daams \& Freudenthal, p. 14 , fig. 8.

2003 Cricetodon spp. from TOR2, TOR3A and TOR3B. Álvarez-Sierra et al., p. 30, table 1.

2004 Cricetodon sp. - Azanza et al., p. 273, table 2.

2009 Cricetodon aff. jotae. - López-Guerrero et al., p. $161 \mathrm{~A}$.

Holotype. - Left m1, TOR3A-321 (Fig. 4H).

Paratypes. - M1: TOR3A-118-TOR3A-131, TOR3A-268TOR3A-270, TOR3A-278; M2: TOR3A-138-TOR3A-166, TOR3A-287; M3: TOR3A-218-TOR3A-237, TOR3A-260TOR3A-236; m1: TOR3A-168-TOR3A-197, TOR3A-317TOR3A-322; m2: TOR3A-198-TOR3A-217, TOR3A-323TOR3A-326; m3: TOR3A-238-TOR3A-259, TOR3A-267, TOR3A-297.

Type horizon. - Local biozone G3, upper Aragonian, middle Miocene.

Type locality. - TOR3A, province of Zaragoza, Calatayud-Daroca Basin, Spain.

Other localities. - LP5H, TOR2 and TOR3B (see Table 1).

Stratigraphical distribution. - Local biozone G3, MN7/8, upper Aragonian, middle Miocene.

Etymology. - Dedicated to our mentor Dr. Nieves López Martínez who made a great contribution to the palaeontology of micromammals.

Diagnosis. - Medium-sized Cricetodontini with thick enamel. The main valleys of the upper molars are almost closed by large cingular ridges and/or styles; the latter are 
Paloma López-Guerrero et al. • New Cricetodontini from the middle Miocene of Europe
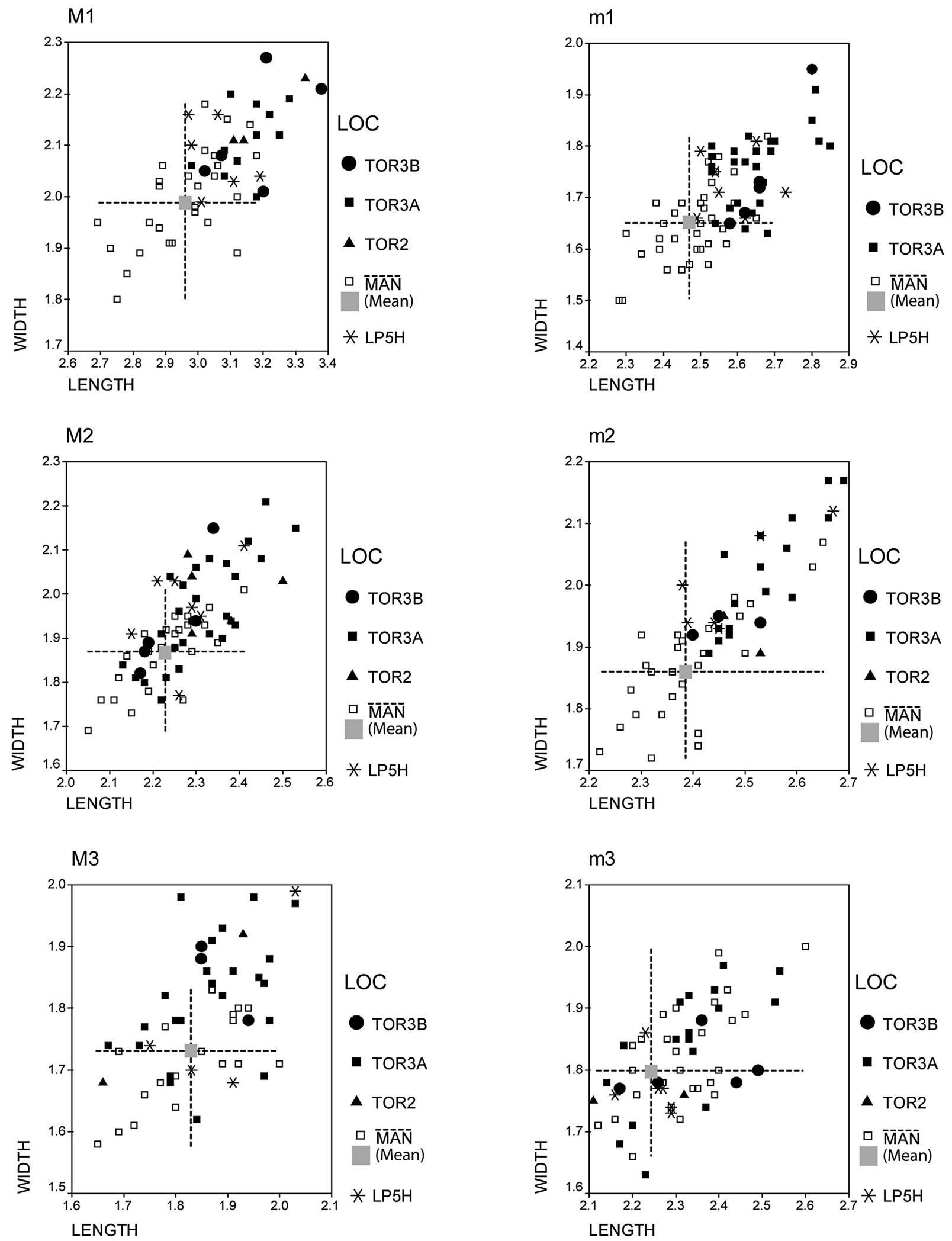

Figure 3. Length/Width scatter-diagram of the cheek teeth in Cricetodon nievei sp. nov. and Cricetodon jotae from Manchones. 
especially frequent in the protosinus. Upper molars always have a short mesoloph except for the M3 where the mesoloph can be absent. M1 with four roots and the anterocone well divided by a groove. The anterior ectoloph is frequently present, simple and not complete. The posterior ectoloph is always present, simple and not complete. The posteroloph, in the M3, is absent. The lower molars present a short mesolophid. The metalophulid I on the $\mathrm{m} 1$ is always present and the metalophulid II is absent. The $\mathrm{m} 1$ and $\mathrm{m} 2$ frequently have a well-developed ectomesolophid which can reach the labial border. The $\mathrm{m} 2$ is generally birradiculated; in some cases, its posterior root is partly divided.

Differential diagnosis. - Cricetodon nievei sp. nov. differs from C. caucasicus Argyropulo, 1938, C. versteegi De Bruijn, Fahlbusch, Saraç \& Ünay, 1993, C. tobieni De Bruijn, Fahlbusch, Saraç \& Ünay, 1993, C. aliveriensis Klein Hofmeijer \& De Bruijn, 1988, C. kasapligili De Bruijn, Fahlbusch, Saraç \& Ünay, 1993, and C. wanhei Qiu, 2010 by its larger size.

Cricetodon nievei sp. nov. differs from $C$. engesseri Rummel \& Kälin, 2003, C. soriae López Martínez, Cárdaba, Salesa, Hernández Fernández, Cuevas González \& Fesharaki, 2006 in Hernández Fernández et al. 2006, C. jumaensis Rummel, 2001, C. klariankae Hír, 2007, C. albanensis Mein \& Freudenthal, 1971a, C. sansaniensis Lartet, 1851 and C. aureus Mein \& Freudenthal, 1971b by its smaller size.

Cricetodon nievei sp. nov. differs from C. pasalariensis (Tobien, 1978) by the deeply split anterocone in the M1; its M2 and M3 with less-developed lingual anterolophs and the absence of metalophulid II in the m1. It differs from C. candirensis (Tobien, 1978) and C. hungaricus (Kordos, 1986) by its less-developed ectolophs; the presence of metalophulid I on the $\mathrm{m} 1$; the absence of the connections in "X-shaped" pattern among the four main cusps in the m3. Differs from C. cariensis (Sen \& Ünay, 1979) by its welldeveloped ectolophs - which do not form a continuous structure -, and the absence of enamel coated valley. Differs from C. bolligeri Rummel, 1995 by the absence of anterior protolophule on the M1, and its less developed ectomesolophid on the m1. Differs from C. meini Freudenthal, 1963 by its presence of posterior ectoloph; the absence of anterior protolophule on the M1 and metalophulid II on the m1. Differs from $C$. jotae Mein \& Freudenthal, 1971a by the presence of styles on the protosinus of the M1; the presence of mesolophs on the upper molars; its protocone connected to the longitudinal crest through the posterior arm of the protocone; the absence of metalophulid II. Differs from C. volkeri $\mathrm{Wu}$, Meng, Ye, Ni, Bi \& Wei, 2009 by its M1 with four roots and less-developed posteroloph; M2 with less-developed mesolophs; larger m2. Differs from "Cricetodon" fandli Prieto, Böhme \& Gross, 2010 by the
M1 without double, and complete anterior ectoloph and m1 without metalophulid II.

Cricetodon nievei sp. nov. differs from Hispanomys dispectus Agustí, 1980 by its M1 with poor-developed ectolophs, its sinuous contour; the absence of enamel coated valley and the $\mathrm{m} 1$ without metalophulid II. Differs from H. daamsi Agustí, Casanovas-Vilar \& Furió, 2005 and H. lavocati (Freudenthal, 1966) by its smaller size; the presence of mesoloph and poor-developed and the not complete ectolophs on the upper molars. Differs from H. aguirrei (Sesé Benito, 1977) by the absence of metalophulid II on the $\mathrm{m} 1$; the poor-developed ectolophs on the M1. Differs from $H$. bijugatus Mein \& Freudenthal, 1971a by the $\mathrm{m} 1$ without metalophulids II and the absence of enamel coated valley. Differs from $H$. decedens (Schaub, 1925) by its sinuous contour on the M1 and the absence of metalophulid II. Differs from H. castelnovi Aguilar, Clavet \& Michaux, 1994 by its bigger size. Differs from $H$. nombrevillae (Freudenthal, 1966); H. adroveri Agustí, 1986; H. baixasi Aguilar, Michaux \& Lazzari, 2007; H. peralensis Van de Weerd, 1976; H. moralesi López-Antoñanzas, Peláez-Campomanes, Álvarez-Sierra \& García-Paredes, 2010; H. mediterraneus, Aguilar 1982; H. thaleri (Hartemberger, 1965), and $H$. aragonensis (Freudenthal, 1966) by its non-complete ectolophs.

Description of the material from the type locality Toril 3A. -

M1. Material: 18 specimens. It has four roots and a sinuous outline. The enamel is thick (Fig. 4B). The anterocone is divided in two parts by a shallow groove on the anterior wall of the tooth. A labial anteroloph is present in five out of 14 molars; this anteroloph is joined to the labial part of the anterocone and is extended through the protosinus, but without reaching the protocone (Fig. 4B, C). The anterolophule is connected to the lingual part of the anterocone. A short labial spur of the anterolophule is present in one specimen. The protolophule is always posterior. The posterior ectoloph of the anterocone is present in most of the cases (10/12; Fig. 4A, B). In one case, this anterior ectoloph is well developed and it reaches the paracone. The posterior ectoloph is always present; it is simple, composed by the posterior ectoloph of the paracone, in most specimens $(11 / 12$; Fig. 4A, C) and it is double, composed by the posterior ectoloph of the paracone and the anterior ectoloph of the metacone, in one case. None of them is complete. The mesoloph is present in all specimens but one (14/15), being short in most cases (13/15; Fig. 4A-C); it is reduced to an enlargement of the enamel (incipient) in one case. A ridge-like structure is present in the anterior wall of the protocone in six out of 14 specimens (Fig. 4A, B), being absent in the remaining ones (8/14; Fig. 4C). The enamel coated valley is absent. The entomesoloph is present in 

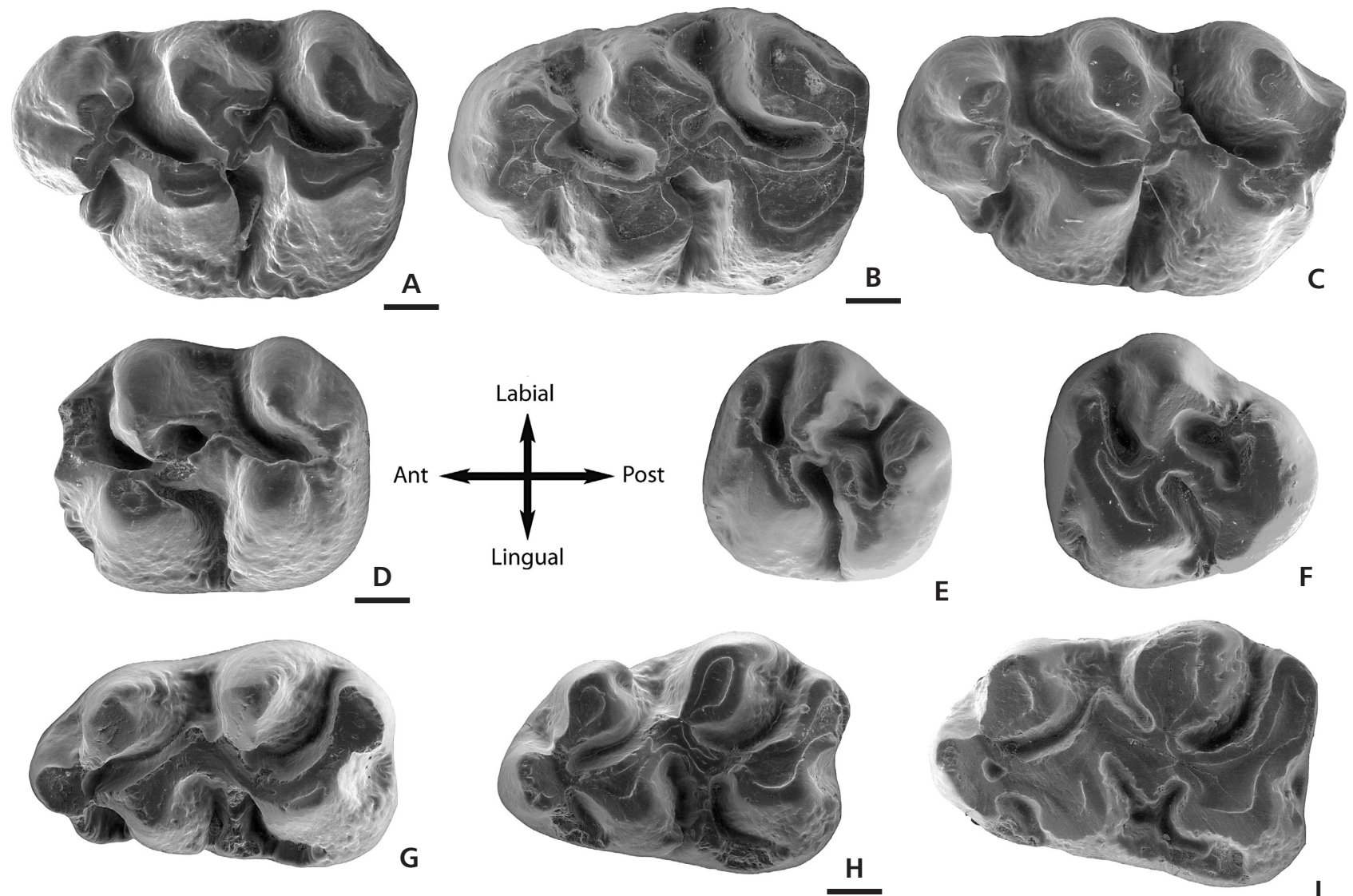

E

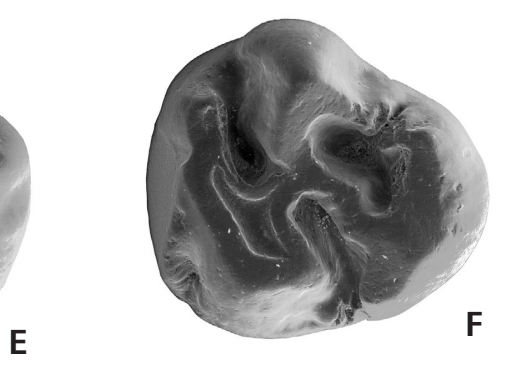

G
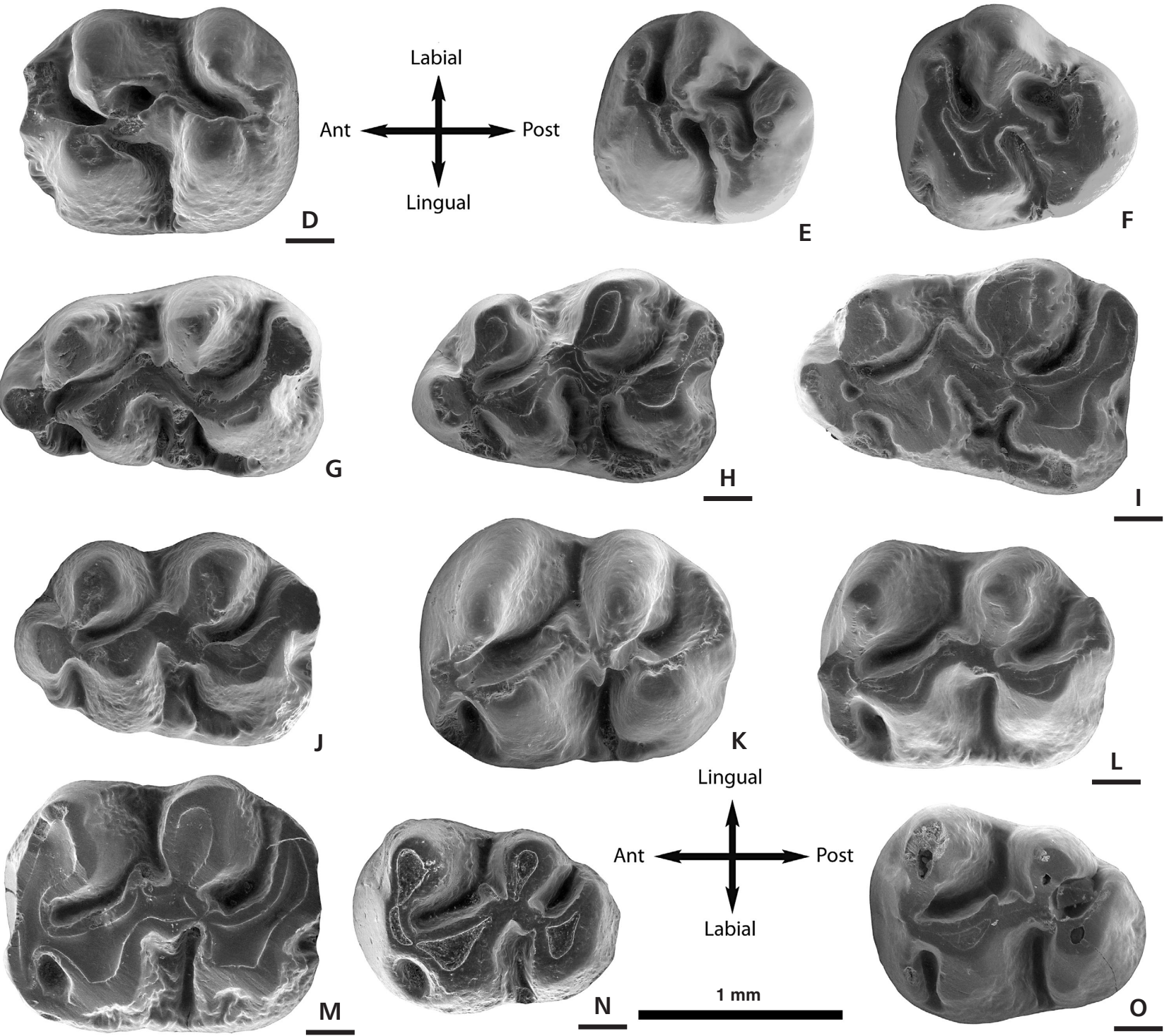

Figure 4. Cricetodon nievei sp. nov. from the Calatayud-Daroca Basin. Toril 3A. $\bullet$ A - inverted right M1, TOR3A-126. $\bullet$ B - inverted right M1, TOR3A-127. $\cdot \mathrm{C}$ - left M1, TOR3A-122. • D - inverted right M2, TOR3A-159. • E - left M3, TOR3A-219. • F - left M3 TOR3A-260. $\bullet$ G - left m1, TOR3A-318. $\bullet$ H - inverted right m1, TOR3A-322 holotype. $\bullet$ I - inverted right m1, TOR3A-169. $\bullet$ J l left m1, TOR3A-176. $\bullet \mathrm{K}-$ left m2, TOR3A-327. $\bullet \mathrm{L}-$ inverted right m2, TOR3A-201. • M - inverted right m2, TOR3A-207. • $\mathrm{N}$ - inverted right m3, TOR3A-259. • O - inverted right m3, TOR3A-242. Scale bar represent $1 \mathrm{~mm}$.

some specimens (2/13) and it is short (Fig. 4B). The labial posteroloph is always present, small, but well delimited (Fig. 4A-C). The lingual posteroloph is mostly present (8/10; Fig. 4A, C). The anterosinus is closed by a well- developed and large cingulum (10/12; Fig. 4A-C); by a style (1/12) or it can also remain open (1/12). The mesosinus is blocked by a big cingulum (10/12; Fig. 4A, B); it is open in two cases (Fig. 4C). The sinus is lingually open 
Table 2. Length and width of the upper and lower molars Cricetodon nievei $\mathrm{sp}$. nov. Units are given in mm. Min = minimum values; Max = maximum values; $\mathrm{SD}=$ standard deviation; $\mathrm{N}=$ number of specimens.

\begin{tabular}{|c|c|c|c|c|c|c|c|c|c|c|c|}
\hline & \multirow[b]{2}{*}{ Locality } & \multicolumn{5}{|c|}{ Length } & \multicolumn{5}{|c|}{ Width } \\
\hline & & Min & Mean & Max & SD & $\mathrm{N}$ & Min & Mean & Max & SD & $\mathrm{N}$ \\
\hline \multirow[t]{4}{*}{ M1 } & TOR3B & 3.02 & 3.18 & 3.38 & 0.140 & 5 & 1.96 & 2.10 & 2.27 & 0.120 & 6 \\
\hline & TOR3A & 2.98 & 3.15 & 3.28 & 0.088 & 11 & 2.00 & 2.12 & 2.20 & 0.064 & 12 \\
\hline & TOR2 & 3.11 & 3.19 & 3.33 & 0.119 & 3 & 2.11 & 2.15 & 2.23 & 0.069 & 3 \\
\hline & LP5H & 2.97 & 3.05 & 3.19 & 0.085 & 6 & 1.99 & 2.08 & 2.16 & 0.071 & 6 \\
\hline \multirow[t]{4}{*}{ M2 } & TOR3B & 2.12 & 2.22 & 2.34 & 0.084 & 6 & 1.82 & 1.94 & 2.15 & 0.010 & 8 \\
\hline & TOR3A & 2.13 & 2.31 & 2.53 & 0.097 & 26 & 1.76 & 1.96 & 2.21 & 0.119 & 26 \\
\hline & TOR2 & 2.28 & 2.35 & 2.50 & 0.094 & 5 & 1.91 & 2.00 & 2.09 & 0.074 & 5 \\
\hline & LP5H & 2.15 & 2.26 & 2.41 & 0.077 & 8 & 1.77 & 1.96 & 2.11 & 0.103 & 8 \\
\hline \multirow[t]{4}{*}{ M3 } & TOR3B & 1.85 & 1.88 & 1.94 & 0.052 & 3 & 1.54 & 1.78 & 1.90 & 0.165 & 4 \\
\hline & TOR3A & 1.63 & 1.85 & 2.03 & 0.104 & 24 & 1.62 & 1.82 & 1.98 & 0.097 & 24 \\
\hline & TOR2 & 1.66 & 1.80 & 1.93 & 0.191 & 2 & 1.68 & 1.80 & 1.92 & 0.170 & 2 \\
\hline & LP5H & 1.75 & 1.88 & 2.03 & 0.119 & 4 & 1.68 & 1.78 & 1.99 & 0.144 & 4 \\
\hline \multirow[t]{3}{*}{ m1 } & TOR3B & 2.58 & 2.66 & 2.8 & 0.074 & 6 & 1.65 & 1.74 & 1.95 & 0.109 & 6 \\
\hline & TOR3A & 2.32 & 2.64 & 2.85 & 0.111 & 29 & 1.27 & 1.74 & 1.91 & 0.074 & 27 \\
\hline & LP5H & 2.49 & 2.58 & 2.73 & 0.088 & 6 & 1.66 & 1.74 & 1.81 & 0.055 & 7 \\
\hline \multirow[t]{4}{*}{$\mathrm{m} 2$} & TOR3B & 2.29 & 2.42 & 2.53 & 0.100 & 4 & 1.92 & 1.98 & 2.14 & 0.091 & 5 \\
\hline & TOR3A & 2.43 & 2.54 & 2.69 & 0.084 & 16 & 1.89 & 2.02 & 2.17 & 0.088 & 19 \\
\hline & TOR2 & 2.46 & 2.50 & 2.53 & 0.049 & 2 & 1.89 & 1.96 & 2.03 & 0.070 & 3 \\
\hline & LP5H & 2.00 & 2.41 & 2.67 & 0.102 & 8 & 1.58 & 1.94 & 2.12 & 0.081 & 7 \\
\hline \multirow[t]{4}{*}{ m3 } & TOR3B & 2.17 & 2.34 & 2.49 & 0.130 & 5 & 1.77 & 1.80 & 1.88 & 0.044 & 5 \\
\hline & TOR3A & 2.14 & 2.33 & 2.54 & 0.113 & 18 & 1.63 & 1.84 & 1.97 & 0.007 & 18 \\
\hline & TOR2 & 2.11 & 2.22 & 2.32 & 0.148 & 2 & 1.75 & 1.76 & 1.76 & 0.098 & 2 \\
\hline & LP5H & 2.16 & 2.25 & 2.29 & 0.049 & 6 & 1.73 & 1.77 & 1.86 & 0.046 & 6 \\
\hline
\end{tabular}

(7/12; Fig. 4B) or closed either by a large style $(3 / 12$; Fig. 4C), or by two crests joined to the hypocone and the protocone (2/12). The protosinus is closed by a big style in 9 out of 14 molars (Fig. 4A); it is closed by the lingual anteroloph on the others (Fig. 4B, C).

M2. Material: 30 specimens. The anterior ectoloph is present in most cases (19/21); it is composed by the anterior ectoloph of the paracone in four molars and it seems to be an enlargement of the enamel at the base of the paracone in the others (Fig. 4D). The posterior ectoloph is always present and composed by the posterior ectoloph of the paracone; it is never connected to the metacone (Fig. 4D) but in two cases, is lingually curved and connected to the mesoloph (Fig. 4D). The mesoloph is short (15/27; Fig. 4D), incipient $(5 / 27)$ or absent (7/27). A spur on the posterior wall of the protocone is present in nine out of 12 specimens (Fig. 4D). The entomesoloph is only present in one specimen and it is incipient. Labial posteroloph is always present; it is well developed in most specimens (18/23; Fig. 4D) and weak in the remaining ones. The lingual posteroloph is short (10/23) or absent in (13/23; Fig. 4D). The anterosinus can be closed by the connection of the basis of labial anteroloph and the paracone
$(25 / 26)$. The protosinus is weak in all the molars but one; it is closed by a small style in two out of 24 specimens. The mesosinus is blocked by a cingulum (22/27) or remains open (5/27); the cingulum is low in two specimens (Fig. 4D). The sinus is curved forward (9/12; Fig. 4D) or straight (3/12). The sinus is open (19/24; Fig. 4D) or closed (5/24); it is blocked by a thick cingulum (2/5) or by two crests attached to the hypocone and to the protocone $(3 / 5)$.

M3. Material: 27 specimens. It has a rounded outline with a reduced hypocone. The lingual anteroloph is weak although it is clearly distinguishable in most cases $(6 / 7$; Fig. 4E, F). The labial anteroloph is always present and well developed (Fig. 4E, F). The anterior ectoloph is barely present $(5 / 23)$; it is composed by the anterior ectoloph of the paracone and one is complete. The posterior ectoloph is always present; it is double (11/24; Fig. 4F) or single, formed by the posterior ectoloph of the paracone $(13 / 24$; Fig. 4E). In six specimens the posterior ectoloph is complete. Some molars (4/22) have a short mesoloph. The enamel coated valley is absent. The entoloph is continuous and the neo-entoloph is present in five out of 23 cases. The posteroloph is absent; several specimens (3/20) have a con- 
Table 3. Results of the Levenne's and ANOVA tests comparing length and width variables of Cricetodon nievei sp. nov. from the studied assemblages with at least five data. NS = non-significant differences $(P>0.05)$; d.f. $=$ degree of freedom.

\begin{tabular}{lcccc|cccccccc}
\hline \multicolumn{3}{c|}{ Levenne's test } & \multicolumn{1}{c}{ ANOVA } \\
\hline \multicolumn{3}{c}{ Length $(P$-value $)$} & Width $(P$-value $)$ & Length $(P$-value $)$ & d.f.1 & d.f.2 & Width $(P$-value $)$ & d.f.1 & d.f.2 \\
\hline M1 & 0.321 & NS & 0.500 & NS & 0.154 & NS & 3 & 21 & 0.638 & NS & 3 & 23 \\
M2 & 0.593 & NS & 0.169 & NS & 0.080 & NS & 3 & 41 & 0.820 & NS & 3 & 43 \\
M3 & 0.715 & NS & 0.361 & NS & 0.802 & NS & 3 & 29 & 0.827 & NS & 3 & 30 \\
m1 & 0.477 & NS & 0.498 & NS & 0.352 & NS & 2 & 39 & 0.657 & NS & 2 & 38 \\
m2 & 0.774 & NS & 0.727 & NS & 0.101 & NS & 3 & 25 & 0.569 & NS & 3 & 29 \\
m3 & 0.290 & NS & 0.064 & NS & 0.255 & NS & 3 & 27 & 0.205 & NS & 3 & 27 \\
\hline
\end{tabular}

striction on the posterior wall of the hypocone which is not considered as a true posteroloph (Fig. 4E). The sinus is deep, curved and directed forward in the specimens without neo-entoloph (Fig. 4E, F); it is small and straight if the neo-entoloph is present.

m1. Material: 36 specimens. The labial anterolophid is well developed and usually does not reach the protoconid (16/25; Fig. 4H-J); it connects the anteroconid with the protoconid in the rest of cases (Fig. 4H, I). A lingual anterolophid is present in one out of 25 specimens and it does not reach the metaconid. Most of the molars (22/24) have a metalophulid I (Fig. 4G-J) and the remaining ones do not have any metalophulid, the metalophulid II being always absent. The longitudinal ridge bears a mesolophid in nearly half of the specimens (11/21; Fig. 4G, I), and it is clearly distinguishable but short in all cases but one, which is incipient. The ectomesolophid is usually present (16/26); it is long, reaching the labial border (2/16; Fig. 4G, H, J) or ending before the labial edge (7/16), and it is short in seven out of 16 specimens (Fig. 4I). The metaconid and the entoconid have, in general, posteriorly directed protuberance near the lingual border (Fig. 4G-I). The hypolophulid is transversal $(3 / 27$; Fig. 4I) or strongly directed forward (24/27; Fig. 4G, H, J). A small labial posterior cingulum is present in three out of 26 cases (Fig. 4G). The mesosinusid is blocked by a low cingular ridge $(3 / 11$; Fig. $4 \mathrm{G}, \mathrm{I})$; closed by a stylid (3/11) or it is open $(5 / 11$; Fig. $4 \mathrm{H}-\mathrm{J})$. The sinusid is wide and shallow; it is straight and it is blocked by a low cingular ridge (15/19; Fig. $4 \mathrm{H})$, by two crests attached to the hypoconid and the protoconid (1/19), or by a stylid with a crest attached to the hypocone (2/19). The sinusid is open in one molar. The posterosinusid is blocked by a cingular ridge $(3 / 26)$ or it remains open.

m2. Material: 24 specimens. It has two roots; the posterior one is split in the half height in some cases (6/10), but none of the specimens have three complete roots. The labial branch of the anterolophid is well developed and it reaches the protoconid (Fig. 4L, M) in all cases but one (Fig. 4K). The lingual anterolophid is absent (Fig. 4K-M). Most specimens have a mesoloph (20/24); it is short
(19/20; Fig. 4K-M) and the other one present a very reduced form; it is an enlargement of the enamel instead of a "true" mesolophid. Several teeth possesses an ectomesolophid (11/23); it is short (3/11; Fig. 4K) or long and reaching the labial border (8/23; Fig. $4 \mathrm{M})$. There is no anterosinusid and the mesosinusid is open (7/24; Fig. $4 \mathrm{~K}, \mathrm{~L})$ or blocked by a low cingulum (17/24; Fig. 4M). The sinusid is open (2/23), blocked by a low cingular ridge (14/23; Fig. 4K, L), by two crests related to the protocononid and the hypoconid (6/23; Fig. 4K), or by a stylid (1/23). A weak labial posterosinusid is formed on the posterior wall of the hypoconid in most specimens (19/21; Fig. 4M); it is well distinguishable in five of them. The posterosinusid can be blocked by a cingulid (3/21) or by the connection between the posterolophid and the entoconid (8/21); it is open in the remaining ten specimens (Fig. 4K-M).

m3. Material: 24 specimens. The labial anterolophid is long; it reaches the protoconid in 16 out of 19 cases (Fig. 4N). A weak lingual anterolophid is present in one case. The mesolophid is present in most specimens (17/19); it is short (Fig. 4N) and in four teeth it develops a second branch in the ectolophid (Fig. 4O). The ectomesolophid is mostly absent (Fig. 4O); but one tooth possesses a weak enlargement of the enamel (Fig. 4N). The lingual posterolophid is high and extends towards the entoconid. The mesosinus is closed by a low cingulid (11/18; Fig. 4N, O) or it remains open (7/18). The sinusid is blocked by a cingulid (7/16; Fig. 4N), by a stylid (7/16) or it remains open (3/16; Fig. 4O). The posterosinusid is closed by a cingulum $(6 / 18)$ or it is blocked by the posterolophid (7/16; Fig. 4O); it is open in the remaining specimens $(5 / 18$; Fig. $4 \mathrm{~N})$.

\section{Cricetodon nievei sp. nov. from other sites in the Calatayud-Daroca Basin}

The studied assemblages of Cricetodon nievei sp. nov. from TOR2, 3A, 3B and LP5H (Table 1) are morphological and metrically homogeneous (Figs 5, 6). Most characteristic features present in all fossil sites are: the thick enamel, the presence of styles on the protosinus of the M1, the moderate 
development of the ectolophs (Fig. 5A, D, F) - being incomplete in most specimens - , the moderately simple pattern of the M3, the presence of metalophulid I on the $\mathrm{m} 1$ and absence of metalophulid II (Fig. 6A, D), the presence of ectomesolophid, and the moderately reduced $\mathrm{m} 3$ (Table 2).

Although no remarkable differences in morphology are observed in the studied material, there is certain degree of variability in several characters, or state of character, which are absent in the type locality. In the fossils from $\mathrm{LP} 5 \mathrm{H}$, the anterior ectoloph is connected to the basis of the paracone in the M1 (3/6) and M2 (1/9), instead of to the top of the cusp as in the rest. Regarding the M3, LP5H and TOR3B have some specimens with longer mesolophs that can exceed the half of the length of the mesosinus or even reach the labial border (1/3 in LP5H).

On the other hand, $C$. nievei sp. nov. from the type locality do not show significant differences in the metrical variables when compared to other studied samples (Fig. 3, Table 3).

\section{Comparisons and discussion}

\section{Remarks on the genera Cricetodon and Hispanomys}

Before addressing comprehensive comparisons and discussion, it is crucial to clarify some aspects about the genera Cricetodon and Hispanomys.

Many authors (De Bruijn 1976, Sen \& Ünay 1979, Ünay 1980, Ünay \& De Bruijn 1984, De Bruijn et al. 1993, Casanovas-Vilar 2007, Prieto et al. 2010) pointed out that the differences between some genera of Cricetodontini are diffuse because the limit from one to the other is not well defined. These transitions are especially problematic during the late Aragonian: from Cricetodon and Hispanomys in Western Europe as well as from Cricetodon to Byzantinia in the Eastern Mediterranean. Thus, the generic assignment is sometimes very complicated (Prieto et al. 2010).

The genus Cricetodon is described by the following features: large, medium or small sized Cricetodontini with low-crowned cheek teeth, ectolophs of the upper molars are absent or weak, the upper M1 has four roots, anterocone of the M1 single or double and majority of the $\mathrm{m} 1$ with metalophulid I and II present on the same specimen or metalophulid II only, among others (Mein \& Freudenthal 1971a, De Bruijn et al. 1993). In turn, Hispanomys is described as Cricetodontinae of medium size, slight to moderately hypsodont; with either incomplete or complete ectolophs; the anterocone of the M1 with an anterior groove and the M1 with either four or five roots (Van de Weerd 1976). Regarding the presence of metalophulid II, Prieto et al. (2010) pointed out that it is usually absent in the early Hispanomys. However, the same authors did not recommend the use of this structure for the unambiguous separation between Cricetodon and Hispanomys due to its high morphological variability.

De Bruijn \& Ünay (1996) recognized five evolutionary grades of Cricetodontini. Type 1, 2 and 4 are composed exclusively by the species from Anatolia; type 1 and 2 are represented by the basal eastern Cricetodon species, whereas type 4 includes mainly representatives of Byzantinia. The type 3 comprises most of the species of Cricetodon characterized by: M1 and M2 with four roots; a divided anterocone; a posterior ectoloph that varies in length and it may be complete; a short labial posteroloph and an $\mathrm{m} 1$ that has usually metalophulid I and II in the same specimen (De Bruijn \& Ünay 1996). Finally, the type 5 contains the Cricetodontini from south-western Europe, assigned by these authors to Hispanomys and Ruscinomys; the species included here display the following features: frequent presence of five roots in the M1; check teeth, not "stretched" longitudinally and wear flat, especially the third molar.

Prieto et al. (2010) defined six groups of Cricetodontini as well. Group 1 that comprises the middle Miocene Anatolian species of Cricetodon. Group 2, including middle Miocene Cricetodon hungaricus from the localities from Hungary. Group 3 is including Cricetodon klariankae from the late middle Miocene of Hungary. Prieto et al. (2010) proposed an ancestor-descendant relationship between C. klariankae and "Cricetodon" fandli from Austria, so the latter species is also considered in the group 3. Group 4 that includes the early Hispanomys species (middle Miocene to earliest late Miocene) from Spain and France; it is characterized by having less hypsodont and reduced longitudinally "stretched" molars (Prieto et al. 2010). Group 5, which contains brachiodont species of Cricetodon from the middle Miocene characterized by ectolophs that are very short or absent (Prieto et al. 2010, p. 181). And finally, group 6 composed by Cricetodon caucasicus from Georgia, which shows non-split anterocone and no ectolophs. However, Pickford et al. (2000) described complete ectolophs in Cricetodon causasicus and its inclusion in group 3 is now taking in consideration by the author (Prieto, pers. comm.).

The proposal of all these classifications that attempt to order the different groups of species of Cricetodon and Hispanomys, give us an idea about the difficulties that, sometimes, are found when realizing the generic assignation. This problem is particularly noticeable during the late Aragonian, the time interval in which the material studied here is placed.

\section{Comparison with others species of Cricetodontini}

The material of Cricetodontini from TOR2, TOR3A and TOR3B was previously cited and studied by Álvarez-Sierra 


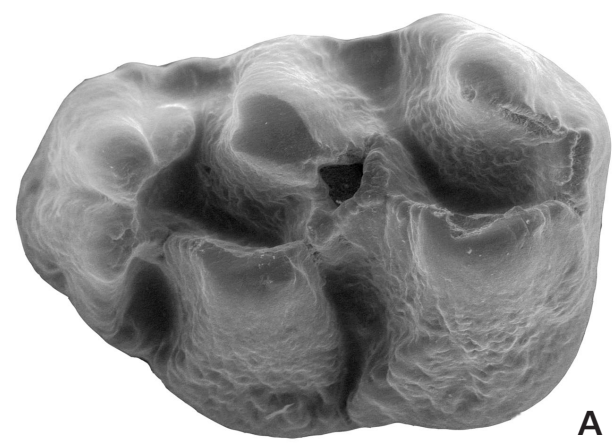

A
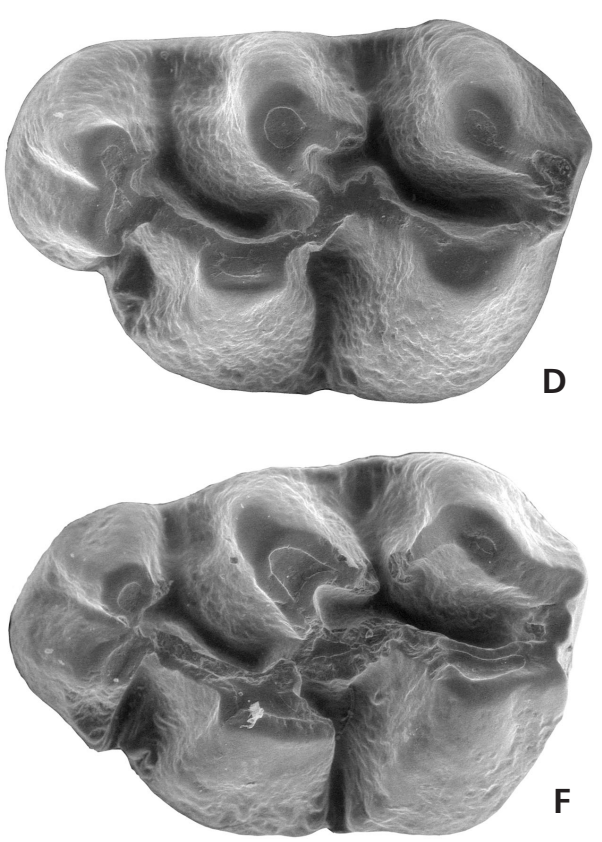
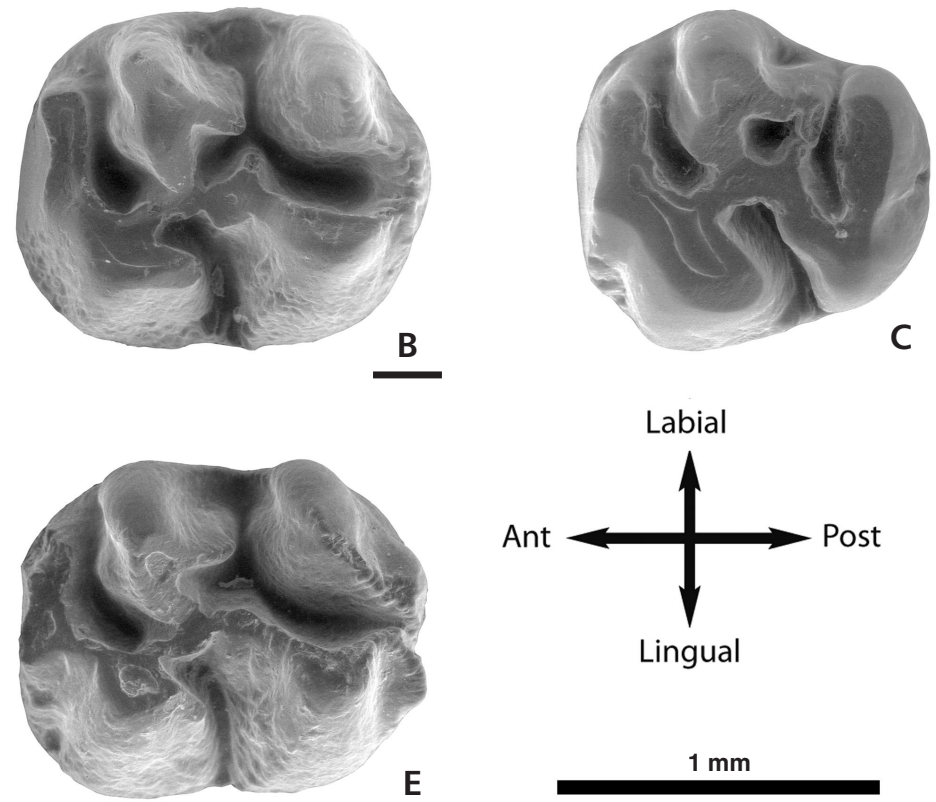

E

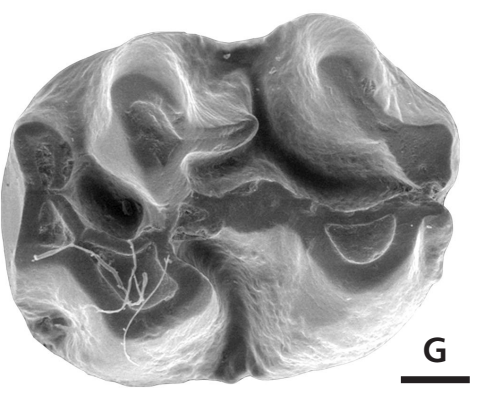

Figure 5. Cricetodon nievei sp. nov. from the Calatayud-Daroca Basin. Upper molars. - Toril 3B: A - left M1, TOR3-143; B - inverted right M2, TOR3-146; C - left M3, TOR3-148; D - left M1, TOR3B-402; E - left M2, TOR3-147. • Toril 2: F - left M1, TOR2-258; G - inverted right M2, TOR2-264; H - left M3, TOR2-267. Scale bar represent $1 \mathrm{~mm}$.

et al. (2003) and López-Guerrero et al. (2009). These authors left the taxonomical assignation as Cricetodon spp. and Cricetodon aff. jotae, respectively. After a new study and descriptions of this material, we have confirmed that the combination of characters is unique and it has not previously been described, allowing us to propose the new taxon.

As we mention before, the generic assignation of the species of Cricetodontini from the late Aragonian is controversial (De Bruijn et al. 1993, Prieto et al. 2010, LópezGuerrero et al. 2013) and as noted by Prieto et al. (2010, p. 425), it "depends on whether the morphological or phylogenetic approach is used". Taking into account these considerations, we discuss, on the first place, the generic ascription of the studied fossils.

The specimens from TOR3A have a combination of primitive and derived characters. The upper molars have the following features: (1) low crowns, (2) sinuous contour, (3) moderate development of the ectolophs which do not form a continuous wall, (4) presence of mesolophs and entomesolophs, cingular formations and styles on the valleys, (5) four-rooted M1, and (6) a barely reduced M3. These characteristics are frequently present in Cricetodon and they are considered as primitive for the tribe (Mein \& Freudenthal 1971a, Agustí 1982, Hír 2007, De Bruijn et al. 1993, López-Antoñanzas \& Mein 2009). On the other hand, the lower molars have: (1) short or absent mesolophids, (2) absence of metalophulid II in the $\mathrm{m} 1$, and (3) three incipient roots in the $\mathrm{m} 2$. These characters are described in many species of Hispanomys and are considered as derived within the tribe Cricetodontini (Mein \& Freudenthal 1971a, Agustí 1982, Hír 2007, De Bruijn et al. 1993, López-Antoñanzas \& Mein 2009, López-Antoñanzas et al. 2010). However, the presence of metalophulid I and the absence of metalophulid II in the $\mathrm{m} 1$, as well as the three rooted $\mathrm{m} 2$ are also found in some species of Cricetodon such as: Cricetodon albanensis, C. bolligeri and C. jumaensis studied by Mein \& Freudenthal (1971a) and Rummel (1995, 2001), respectively. 
In addition, the diagnosis and the descriptions of the different species of Hispanomys frequently pointed out the high hypsodonty (Mein \& Freudenthal 1971a, Van de Weerd 1976); complete and usually double ectolophs forming a continuous wall (Aguilar et al. 1994); the younger species show a short or absent labial anterolophid in the $\mathrm{m} 1$ (López-Antoñanzas \& Mein 2009, 2011); and a hypocone highly reduced in the third molars (Agustí 1982). These characters are absent in the material from TOR3A.

Given that our material presents a large number of characters of Cricetodon, as well as the fact that the characters shared with Hispanomys are also found in some species assigned to Cricetodon, we decided to include the new species of TOR3A in the latter genus; despite of the abovementioned resemblance of its lower molars with Hispanomys. Nevertheless, it is essential to compare our new material with the species included in both genera.

In order to make easier the comparisons with the species of Cricetodon and Hispanomys, these were grouped. Primary order is by age and secondary sort is by size. The species for each group differ from $C$. nievei sp. nov. by at least one of the listed features or a combination of several ones.

Firstly, the material of TOR3A is compared with the older species of Cricetodon. Since the Ramblian until the middle Aragonian, the Cricetodontini remains modest in numbers of both specimens and species (De Bruijn \& Ünay 1996). These species are enclosed in the Cricetodontini types 1, 2 and partially 3 defined by De Bruijn \& Ünay (1996) as well as in the groups 1, 2 and 6 by Prieto et al. (2010). We include in these groups: Cricetodon tobieni, C. wanhei, C. soriae, C. aureus, C. sansaniensis, C. hungaricus, C. candirensis, C. versteegi, C. aliveriensis, C. meini, C. pasalarensis, C. caucasicus, C. volkeri and C. kasapligili. Our new species can be easily differentiated from these species because they possess some of the follow primitive traits: (1) M1 with non-divided anterocone; (2) three roots on the M1; (3) anterior protolophule; and (4) m1 with metalophulid II or both metalophulids, I and II, in the same specimen (Mein \& Freudenthal 1971b, Baudelot 1972, Klein Hofmeijer \& De Bruijn 1988, De Bruijn et al. 1993, Rummel 2001, Hernández-Fernández et al. 2006, Hír 2007, Wu et al. 2009, Qiu 2010, Maridet \& Sen 2012, López-Guerrero et al. 2013).

In turn, the younger representatives of Cricetodontini, from the Vallesian and the Turolian, belong to the type 5 defined by De Bruijn \& Ünay (1996). In this group we include: Hispanomys adroveri, $H$. freudenthali, $H$. baixasi, $H$. peralensis, H. moralesi, H. mediterraneus, $H$. thaleri, $H$. aragonensis and $H$. nombrevillae. These species present complete ectolophs and high degree of hypsodonty. None of these characters are present in the studied material and they confer a clear derivate pattern, according with the trends described by the authors (Mein \& Freudenthal 1971a, Agustí 1982, Hír 2007, López-Antoñanzas \& Mein 2009).

Our material is compared with the contemporary species from the late Aragonian. Among them, there is a group that is clearly larger than the material from TOR3A (Tables 4, 5). This group includes: (A) C. engesseri; (B) C. klariankae (C) C. jumaensis; (D) C. cariensis; (E) C. albanensis, and (F) Hispanomys lavocati. They have also some different features. Each species have, at least, one or more of the following features: (1) long mesolophs and mesolophids (C); (2) complete ectolophs (B, D, F); (3) enamel coated valley in the upper molars (D, E); (4) presence of metalophulid II (B-F); and (5) well-developed posteroloph on the M3 (A) (Sen \& Ünay 1979, Rummel 2001, Rummel \& Kälin 2003, Hír 2007, Kälin \& Kempf 2009, López-Guerrero et al. 2008).

The case of $C$. albanensis from La Grive M (MN7/8) (Mein \& Freudenthal 1971a, De Bruijn et al. 1992) is especially interesting. Despite its larger size, the dental proportions are similar to those in TOR3A. Besides, the morphological resemblance with our material is noticeable. Both species share: the low crowned cheek teeth, the degree of development of ectolophs, which are single and not complete; the presence of large styles on the protosinus; the absence of metalophulid II; the presence of two labial bulges on the entoconid and metaconid in the $\mathrm{m} 1$ and the presence of a bifid anterolophulid in some $\mathrm{m} 1$. However, C. albanensis has a number of traits that differs from the studied material, such as: enamel coated valley on the upper molars, and the absence of both mesoloph and ectomesolophid.

There is another set of species from the late Aragonian which has similar size to that of TOR3A (Tables 4, 5), but displays different morphology. "Cricetodon" fandli, $C$. jotae, $H$. bijugatus and $H$. aguirrei differ from the Cricetodon from TOR3A, because they have metalophulid II or both metalophulids on the same specimen in the $\mathrm{m} 1$ (Sesé Benito 1977; Prieto et al. 2010; López-Guerrero et al. 2008; López-Antoñanzas \& Mein 2009, 2011). Cricetodon bolligeri has anterior protolophule on the M1 and a more developed entomesolophid on the lower molars (Rummel 1995). Hispanomys dispectus possesses double and complete ectolophs and a straight contour (Agustí 1980). Hispanomys daamsi has no mesoloph; the anterior and posterior ectolophs are complete and the latter is double (Agustí et al. 2005).

The case of Hispanomys decedens needs special attention since it shows quite basal morphology shared with the molars from TOR3A such as: the presence of lingual cingulum closing the valleys, incomplete anterior ectolophs, the presence of mesolophs, four-rooted M1, and low-reduced M3 (López-Antoñanzas \& Mein 2011). Despite these similarities, $H$. decedens shows some differences like the enamel coated valley, complete posterior ectolophs in 

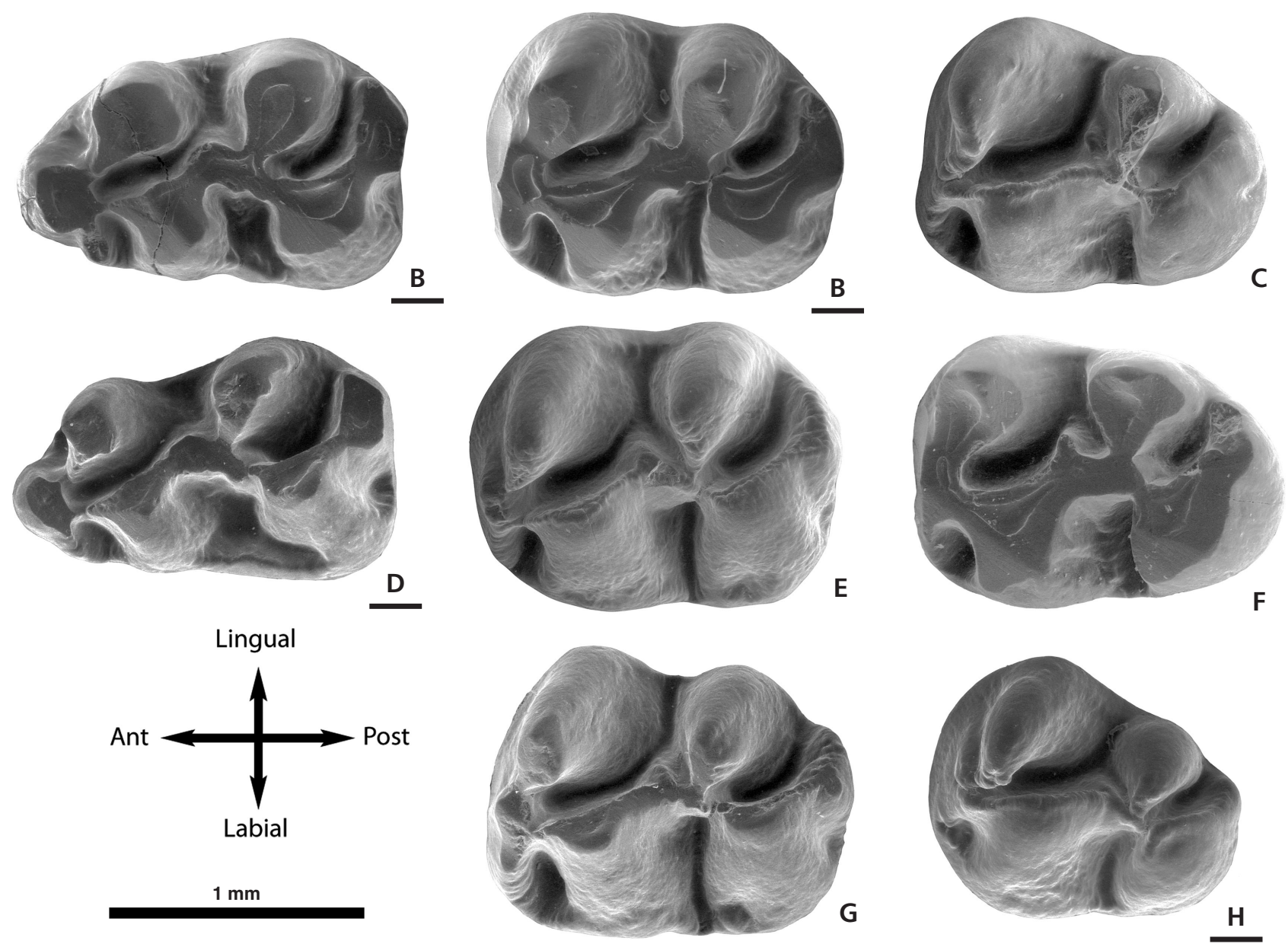

Figure 6. Cricetodon nievei sp. nov. from the Calatayud-Daroca Basin. Lower molars. $\bullet$ Toril 3B: A -inverted right m1, TOR3B-420; B -inverted right m2, TOR3B-426; C-left m3, TOR3B-433; D - inverted right m1, TOR3B-418; E-left m2, TOR3B-431; F-left m3, TOR3B-432. • Toril 2: G-left m2, TOR2-271; $\mathrm{H}$ - inverted right $\mathrm{m} 3$, TOR2-274. Scale bars equals $0.5 \mathrm{~mm}$ and $1 \mathrm{~mm}$.

the upper molars, as well as a well-developed posteroloph on the M3 (López-Antoñanzas \& Mein 2011), which preclude the assignment of our material to $H$. decedens.

Finally, there is one species that is smaller than the molars from TOR3A (Tables 4, 5), H. castelnovi. This species displays also morphological differences with the studied fossils; it has the anterocone slightly divided in the M1 and both ectolophs are complete, forming a continuous wall in the upper molars (Aguilar et al. 1994).

A large number of forms of Cricetodontini have been described from the late Aragonian and early Vallesian in Central Europe. In the Swiss Molasse of the North Alpine Foreland Basin (NAFB) Hispanomys sp. from Nebelberg TGL II+III (MN9) (Kälin \& Kempf 2009) is similar in size and morphology to the material from TOR3A. Both possess M1 with weak posterior ectoloph and absence of anterior ectoloph, and $\mathrm{m} 1$ having mesolophid and metalophulid I, but lacking metalophulid II (Kälin \& Kempf 2009, Rummel \& Kälin 2003). These resemblances indicate that the Swiss specimens could fit the diagnosis of the new species from TOR3A; however, the revision and study of this material is necessary to confirm this statement.

Rummel (2000) reported Cricetodon aff. sansaniensis from the locality Petersbuch 31 (MN7) in the German Molasse of the NAFB. It displays several similarities with the species from TOR3A: both have weak-developed and not complete ectolophs on the upper molars, short mesolophids on the $\mathrm{m} 1$ and, generally, three roots on the $\mathrm{m} 2$ : the posterior one can be completely or partially split (Rummel 2000). Furthermore, Cricetodon aff. sansaniensis is similar in size to the species from TOR3A, although the $\mathrm{m} 2$ and $\mathrm{m} 3$ are slightly larger and, therefore, its Length $\mathrm{m} 1 /$ Length $\mathrm{m} 3$ index is lower (1.08 vs. 1.12, respectively). Besides, it shows metalophulid II in one out of six specimens. All these features preclude the assignation of Cricetodon aff. sansaniensis to the species from TOR3A.

After the detailed morphometrical study and the comparison with all species above mentioned, it is justified the proposal of the new species Cricetodon nievei sp. nov. for the material from TOR3A, TOR3B, TOR2 and LP5H. 
Table 4. Length and width of the upper molars of medium sized species of Cricetodon and the older species of Hispanomys. Units are given in mm. Min = minimum values; Max = maximum values; $\mathrm{N}=$ number of specimens.

\begin{tabular}{|c|c|c|c|c|c|c|c|c|c|c|}
\hline & \multicolumn{4}{|c|}{ Length } & \multicolumn{3}{|c|}{ Width } & \multirow[b]{2}{*}{$\operatorname{Max}$} & \multirow[b]{2}{*}{$\mathrm{N}$} & \multirow[b]{2}{*}{ Source of data } \\
\hline & Species & Min & Mean & Max & $\mathrm{N}$ & Min & Mean & & & \\
\hline \multirow[t]{14}{*}{ M1 } & H. dispectus & 2.79 & 3.15 & 3.46 & 27 & 1.77 & 1.98 & 2.24 & 27 & Agustí (1980) \\
\hline & H. daamsi & 3.01 & 3.36 & 3.58 & 3 & 1.70 & 1.92 & 2.04 & 5 & Agustí et al. (2005) \\
\hline & H. lavocati & 3.56 & 3.69 & 3.88 & 6 & 2.09 & 2.22 & 2.34 & 7 & Agustí (1980) \\
\hline & H. aguirrei & 2.68 & 3.08 & 3.50 & 89 & 1.81 & 2.10 & 2.27 & 89 & Sesé Benito (1977) \\
\hline & H. bijugatus & 2.97 & 3.23 & 3.50 & 49 & 1.92 & 2.05 & 2.18 & 49 & López-Antoñanzas \& Mein (2009) \\
\hline & H. decedens & 2.74 & 3.16 & 3.59 & 62 & 1.76 & 2.05 & 2.31 & 62 & López-Antoñanzas \& Mein (2011) \\
\hline & H. castelnovi & 2.66 & 2.88 & 3.06 & 8 & 1.80 & 1.94 & 2.12 & 8 & Aguilar et al. (1994) \\
\hline & “C.” fandli & 2.90 & 3.04 & 3.20 & 4 & 1.90 & 1.92 & 1.97 & 4 & Prieto et al. (2010) \\
\hline & C. bolligeri & 2.96 & 3.20 & 3.44 & 89 & 1.85 & 2.02 & 2.20 & 89 & Rummel (1995) \\
\hline & C. cariensis & 3.25 & 3.33 & 3.40 & 3 & 1.85 & 2.03 & 2.15 & 3 & Sen \& Ünay (1979) \\
\hline & C. jotae & 2.69 & 2.96 & 3.18 & 19 & 1.80 & 2.00 & 2.18 & 19 & pers. obs. \\
\hline & C. pasalarensis & 2.76 & 2.94 & 3.21 & 19 & 1.69 & 1.85 & 1.99 & 19 & Rummel (1998) \\
\hline & C. meini & 2.58 & 2.90 & 3.13 & 105 & 1.82 & 1.96 & 2.11 & 105 & Mein \& Freudenthal (1971b) \\
\hline & C. candirensis & 2.85 & 3.10 & 3.36 & 21 & 1.84 & 1.99 & 2.22 & 21 & Rummel (1998) \\
\hline \multirow[t]{14}{*}{ M2 } & H. dispectus & 2.04 & 2.35 & 2.59 & 23 & 1.71 & 1.92 & 2.14 & 23 & Agustí (1980) \\
\hline & H. daamsi & 2.25 & 2.61 & 2.75 & 6 & 1.83 & 1.97 & 2.20 & 9 & Agustí et al. (2005) \\
\hline & H. lavocati & 2.41 & 2.56 & 2.75 & 4 & 2.05 & 2.12 & 2.23 & 4 & Agustí (1980) \\
\hline & H. aguirrei & 2.04 & 2.35 & 2.63 & 93 & 1.68 & 1.92 & 2.27 & 93 & Sesé Benito (1977) \\
\hline & H. bijugatus & 2.30 & 2.47 & 2.61 & 42 & 1.80 & 1.92 & 2.07 & 42 & López-Antoñanzas \& Mein (2009) \\
\hline & H. decedens & 2.14 & 2.43 & 2.69 & 54 & 1.72 & 1.92 & 2.23 & 54 & López-Antoñanzas \& Mein (2011) \\
\hline & H. castelnovi & 2.06 & 2.18 & 2.29 & 15 & 1.61 & 1.74 & 1.85 & 15 & Aguilar et al. (1994) \\
\hline & "C.". fandli & 2.22 & 2.30 & 2.43 & 4 & 1.78 & 1.82 & 1.88 & 2 & Prieto et al. (2010) \\
\hline & C. bolligeri & 2.21 & 2.43 & 2.65 & 83 & 1.79 & 1.95 & 2.12 & 83 & Rummel (1995) \\
\hline & C. cariensis & 2.65 & 2.70 & 2.75 & 2 & 1.80 & 1.90 & 2.00 & 2 & Sen \& Ünay (1979) \\
\hline & C. jotae & 2.08 & 2.24 & 2.41 & 8 & 1.76 & 1.89 & 2.01 & 8 & pers. obs. \\
\hline & C. pasalarensis & 2.01 & 2.14 & 2.35 & 27 & 1.63 & 1.97 & 1.80 & 27 & Rummel (1998) \\
\hline & C. meini & 2.04 & 2.24 & 2.41 & 106 & 1.71 & 1.92 & 2.12 & 106 & Mein \& Freudenthal (1971b) \\
\hline & C. candirensis & 2.03 & 2.26 & 2.53 & 17 & 1.73 & 1.89 & 2.04 & 17 & Rummel (1998) \\
\hline \multirow[t]{14}{*}{ M3 } & H. dispectus & 1.52 & 1.65 & 1.75 & 6 & 1.52 & 1.59 & 1.69 & 6 & Agustí (1980) \\
\hline & H. daamsi & 1.83 & 1.95 & 2.01 & 6 & 1.73 & 1.78 & 2.04 & 7 & Agustí et al. (2005) \\
\hline & H. lavocati & 1.78 & 1.90 & 2.01 & 4 & 1.74 & 1.86 & 1.98 & 4 & Agustí (1980) \\
\hline & H. aguirrei & 1.54 & 1.74 & 2.04 & 90 & 1.52 & 1.73 & 2.04 & 90 & Sesé Benito (1977) \\
\hline & H. bijugatus & 1.80 & 1.97 & 2.18 & 41 & 1.57 & 1.70 & 1.93 & 41 & López-Antoñanzas \& Mein (2009) \\
\hline & H. decedens & 1.64 & 1.82 & 2.09 & 26 & 1.50 & 1.68 & 1.90 & 26 & López-Antoñanzas \& Mein (2011) \\
\hline & H. castelnovi & 1.45 & 1.57 & 1.72 & 25 & 1.34 & 1.52 & 1.65 & 25 & Aguilar et al. (1994) \\
\hline & “C.” fandli & 1.73 & 1.87 & 1.95 & 6 & 1.57 & 1.69 & 1.82 & 6 & Prieto et al. (2010) \\
\hline & C. bolligeri & 1.79 & 1.96 & 2.14 & 55 & 1.68 & 1.83 & 2.02 & 55 & Rummel (1995) \\
\hline & C. cariensis & - & 2.45 & - & 1 & - & 1.95 & - & 1 & Sen \& Ünay (1979) \\
\hline & C. jotae & 1.69 & 1.87 & 2.00 & 9 & 1.60 & 1.74 & 1.83 & 9 & pers. obs. \\
\hline & C. pasalarensis & 1.65 & 1.78 & 1.97 & 23 & 1.51 & 1.67 & 1.84 & 23 & Rummel (1998) \\
\hline & C. meini & 1.68 & 1.88 & 2.08 & 133 & 1.62 & 1.76 & 1.91 & 133 & Mein \& Freudenthal (1971b) \\
\hline & C. candirensis & 1.85 & 2.00 & 2.25 & 14 & 1.58 & 1.69 & 1.79 & 14 & Rummel (1998) \\
\hline
\end{tabular}




\section{Final remarks and conclusions}

\section{The relationships with the other Cricetodontini present in the Calatayud-Daroca Basin}

The first Cricetodontini from the Calatayud-Daroca Basin is found in the local biozone E (MN5, middle Aragonian). During biozones F, G1 and G2 (MN6, late Aragonian) the species have a homogeneous basal morphology characteristic of Cricetodon. In the biozone G3 (MN7/8, latest late Aragonian) there is an increase of the taxonomic diversity, being registered the highest number of species in the basin. The morphological homogeneity disappears and the intraspecific variability became higher. These species show a combination of primitive and derived characters. Afterwards, the acquisition of derivate characters typical of Hispanomys is achieved during the local biozone $\mathrm{H}$ (ÁlvarezSierra et al. 2003).

In the scenarios described above, $C$. nievei sp. nov. is registered on the interval of maximum diversification together with Cricetodon jotae, Hispanomys aguirrei and H. lavocati. Cricetodon jotae is found in Manchones, Arroyo del Val 6 (local biozone G2, MN6) and TOR 1 (local biozone G3, MN7/8) (Mein \& Freudenthal 1971a; pers. obs.). Hispanomys aguirrei and/or H. lavocati are recorded on the younger localities from the TOR-Nombrevilla section, Nombrevilla 2, 3 and 4 (López-Guerrero et al. 2008, 2009).

Agustí (1982) propose a phylogeny for the Cricetodon-Ruscinomys group, in which $C$. jotae was the ancestor of $H$. aguirrei. He pointed out that the evolutionary trends for this lineage were the development of the ectolophs and the acquisition of a slightly modern pattern consisting of: the increase of the hypsodonty and the reduction of the cingular formations (Agustí 1982, pp. 104, 110). Given that Cricetodon nievei sp. nov. is located in the sites of intermediate age between those which have $C$. jotae and $H$. aguirrei, is necessary to analyse the possible relationships that could exist among this three species.

As we remark before, these three species show, each one, a particular combination of basal and derivate traits. In the case of $C$. jotae from Manchones we observe a primitive character as the metalophulid II present in many specimens and, however, it has the following features that are considered derivate for the tribe (Agustí 1980, LópezAntoñanzas \& Mein 2009): absence of mesolophs; presence of double ectolophs and styles in the protosinus of only few M1; low-developed or absent mesolophids; absence of ectomesolophid and weak or absent labial anterolophid of the $\mathrm{m} 1$. In contrast, Cricetodon nievei sp. nov. has mesoloph/ids; only one M1 has double ectolophs, styles are more frequent on the protosinus; ectomesolophid present; well-developed labial anterolophid, and metalophulid I in the $\mathrm{m} 1$; furthermore, neo-entolophs are present the M3 and it present bigger size (Fig. 3).
In the case of $H$. aguirrei, it displays primitive features like: the anterocone on the M1 poorly divided; presence of metalophulids I and II in the same specimen; two roots in the m2 (López Martínez et al. 1977, Sesé Benito 1977, López-Guerrero et al. 2008), whereas both $C$. jotae and $C$. nievei sp. nov. possesses well-divided anterocone and some of their $\mathrm{m} 2$ have three roots. But, on the other hand, the ectolophs are complete in a high number of molars (Sesé Benito 1977; López-Guerrero et al. 2008) and it is a derived feature absent in $C$. jotae as well as in $C$. nievei sp. nov.

The observed morphology, combining primitive and derivate traits in a particular manner for each species, suggests a mosaic evolution. This consists in different rates of change in the jugal teeth, which result in a degree of uncoupling between the upper and lower features (Stebbins 1983, López Martínez 1997, Hopkins \& Lidgard 2012). Furthermore, this mosaic evolution is also recognized in other Cricetodontini from the European late Aragonian (De Bruijn et al. 1993, De Bruijn \& Ünay 1996). This fact supposes an additional difficulty for establishing the phylogenetic relationships between the involved taxa $C$. jotae, $C$. nievei sp. nov. and H. aguirrei. Therefore, these questions need a separate study, which is beyond the scope of this study, and they should be resolved through the cladistic analysis that is currently in progress. In line with this, a previous cladistics phylogeny, Sen \& Erbajeva (2011) propose that Cricetodon might be paraphyletic, since its species were gruped in different clades. The resulting cladogram allocates $C$. albanensis in a clade with Byzantinia, whereas the other European species like C. jotae and C. sansaniensis are grouped on another clade together with some Asian taxa. Nonetheless, the phylogeny made by Sen \& Erbajeva (2011) do not include Hispanomys and these results has to be taken carefully.

After making detailed comparisons with the rest of European and Asian species of Cricetodon and Hispanomys we are allowed to point out a morphological resemblance of $C$. nievei sp. nov. with the species of Cricetodon and Hispanomys from the Vallès-Penedès, France and Central Europe, especially C. albanensis and H. decedens, that has to be assessed in a complete cladistics analysis.

Having discussed and compared Cricetodon nievei sp. nov., $C$. jotae and Hispanomys aguirrei, it is important to mention Hispanomys lavocati from Nombrevilla 2, Nombrevilla 3 and Nombrevilla 4 (López-Guerrero et al. 2008, 2009). It shows a general pattern more derivate than C. nievei sp. nov.; it consists of: ectolophs always present, some of them double and, frequently, complete; the metalophulid I always present, and the metalophulid II absent (pers. obs.); the $\mathrm{m} 2$ has always three roots and the posterior one is mostly completely split. The mosaic morphology is also perceived in this species by the presence of short mesoloph-ids in a considerably number of specimens 
Table 5. Length and width of the lower molars of medium sized species of Cricetodon and the older species of Hispanomys. Units are given in mm. Min = minimum values; Max = maximum values; $\mathrm{N}=$ number of specimens.

\begin{tabular}{|c|c|c|c|c|c|c|c|c|c|c|}
\hline & & \multicolumn{4}{|c|}{ Length } & \multicolumn{4}{|c|}{ Width } & \multirow[b]{2}{*}{ Source of data } \\
\hline & Species & Min & Mean & Max & $\mathrm{N}$ & Min & Mean & Max & $\mathrm{N}$ & \\
\hline \multirow[t]{14}{*}{$\mathrm{m} 1$} & H. dispectus & 2.29 & 2.59 & 2.90 & 19 & 1.48 & 1.70 & 1.89 & 19 & Agustí (1980) \\
\hline & H. daamsi & 2.45 & 2.67 & 2.94 & 9 & 1.55 & 1.72 & 1.95 & 10 & Agustí et al. (2005) \\
\hline & H. lavocati & 2.53 & 2.82 & 2.98 & 8 & 1.85 & 1.89 & 2.01 & 8 & Agustí (1980) \\
\hline & H. aguirrei & 2.36 & 2.63 & 2.95 & 84 & 1.59 & 1.78 & 2.00 & 84 & Sesé Benito (1977) \\
\hline & H. bijugatus & 2.44 & 2.60 & 2.80 & 50 & 1.54 & 1.63 & 1.81 & 50 & López-Antoñanzas \& Mein (2009) \\
\hline & H. decedens & 2.44 & 2.60 & 2.80 & 29 & 1.60 & 1.69 & 1.78 & 29 & López-Antoñanzas \& Mein (2011) \\
\hline & H. castelnovi & 2.27 & 2.39 & 2.60 & 10 & 1.47 & 1.57 & 1.70 & 12 & Aguilar et al. (1994) \\
\hline & “C." fandli & 2.35 & 2.43 & 2.55 & 2 & 1.55 & 1.66 & 1.77 & 4 & Prieto et al. (2010) \\
\hline & C. bolligeri & 2.35 & 2.60 & 2.79 & 61 & 1.53 & 1.86 & 1.72 & 61 & Rummel (1995) \\
\hline & C. cariensis & 2.60 & 2.66 & 2.75 & 3 & 1.72 & 1.80 & 1.85 & 4 & Sen \& Ünay (1979) \\
\hline & C. jotae & 2.05 & 2.44 & 2.68 & 28 & 1.50 & 1.63 & 1.82 & 28 & pers. obs. \\
\hline & C. pasalarensis & 2.22 & 2.42 & 2.57 & 16 & 1.46 & 1.60 & 1.70 & 16 & Rummel (1998) \\
\hline & C. meini & 2.19 & 2.41 & 2.57 & 90 & 1.42 & 1.57 & 1.73 & 90 & Mein \& Freudenthal (1971b) \\
\hline & C. candirensis & 2.32 & 2.47 & 2.76 & 23 & 1.56 & 1.70 & 1.82 & 23 & Rummel (1998) \\
\hline \multirow[t]{14}{*}{$\mathrm{m} 2$} & H. dispectus & 2.29 & 2.59 & 2.90 & 19 & 1.48 & 1.70 & 1.89 & 41 & Agustí (1980) \\
\hline & H. daamsi & 2.52 & 2.58 & 2.70 & 4 & 1.87 & 2.02 & 1.93 & 4 & Agustí et al. (2005) \\
\hline & H. lavocati & 2.46 & 2.66 & 2.81 & 11 & 1.97 & 2.07 & 2.21 & 11 & Agustí (1980) \\
\hline & H. aguirrei & 2.18 & 2.48 & 2.77 & 101 & 1.77 & 2.02 & 2.27 & 101 & Sesé Benito (1977) \\
\hline & H. bijugatus & 2.40 & 2.54 & 2.74 & 43 & 1.65 & 1.83 & 1.93 & 43 & López-Antoñanzas \& Mein (2009) \\
\hline & H. decedens & 2.27 & 2.48 & 2.69 & 34 & 1.80 & 1.94 & 2.08 & 34 & López-Antoñanzas \& Mein (2011) \\
\hline & H. castelnovi & 2.32 & 2.35 & 2.39 & 12 & 1.71 & 1.76 & 1.84 & 14 & Aguilar et al. (1994) \\
\hline & "C." fandli & 2.27 & 2.43 & 2.53 & 5 & 1.73 & 1.84 & 1.87 & 5 & Prieto et al. (2010) \\
\hline & C. bolligeri & 2.19 & 2.52 & 2.71 & 59 & 1.75 & 1.91 & 2.01 & 59 & Rummel (1995) \\
\hline & C. cariensis & 2.65 & 2.68 & 2.70 & 4 & 1.90 & 2.02 & 2.10 & 5 & Sen \& Ünay (1979) \\
\hline & C. jotae & 2.22 & 2.39 & 2.65 & 27 & 1.72 & 1.87 & 2.07 & 27 & pers. obs. \\
\hline & C. pasalarensis & 2.09 & 2.26 & 2.41 & 29 & 1.61 & 1.75 & 1.92 & 29 & Rummel (1998) \\
\hline & C. meini & 2.14 & 2.33 & 2.51 & 88 & 1.71 & 1.83 & 2.05 & 88 & Mein \& Freudenthal (1971b) \\
\hline & C. candirensis & 2.21 & 2.40 & 2.58 & 17 & 1.70 & 1.82 & 1.90 & 17 & Rummel (1998) \\
\hline \multirow[t]{14}{*}{$\mathrm{m} 3$} & H. dispectus & 1.87 & 2.13 & 2.33 & 27 & 1.49 & 1.71 & 1.89 & 27 & Agustí (1980) \\
\hline & H. daamsi & 2.38 & 2.47 & 2.60 & 4 & 1.72 & 1.88 & 1.98 & 5 & Agustí et al. (2005) \\
\hline & H. lavocati & 2.43 & 2.54 & 2.74 & 5 & 1.88 & 1.98 & 2.00 & 5 & Agustí (1980) \\
\hline & H. aguirrei & 1.95 & 2.18 & 2.45 & 78 & 1.54 & 1.75 & 1.97 & 78 & Sesé Benito (1977) \\
\hline & H. bijugatus & 2.32 & 2.47 & 2.72 & 39 & 1.58 & 1.68 & 1.80 & 39 & López-Antoñanzas \& Mein (2009) \\
\hline & H. decedens & 1.92 & 2.23 & 2.42 & 25 & 1.63 & 1.79 & 1.93 & 25 & López-Antoñanzas \& Mein (2011) \\
\hline & H. castelnovi & 1.90 & 2.09 & 2.20 & 5 & 1.57 & 1.64 & 1.74 & 5 & Aguilar et al. (1994) \\
\hline & “C." fandli & 2.08 & 2.23 & 2.32 & 7 & 1.60 & 1.69 & 1.78 & 7 & Prieto et al. (2010) \\
\hline & C. bolligeri & 2.16 & 2.36 & 2.63 & 44 & 1.76 & 1.88 & 2.03 & 44 & Rummel (1995) \\
\hline & C. cariensis & 2.08 & 2.65 & 2.74 & 4 & 1.70 & 1.87 & 2.00 & 5 & Sen \& Ünay (1979) \\
\hline & C. jotae & 2.20 & 2.30 & 2.43 & 10 & 1.66 & 1.83 & 1.99 & 10 & pers. obs. \\
\hline & C. pasalarensis & 2.10 & 2.30 & 2.50 & 32 & 1.48 & 1.66 & 1.89 & 32 & Rummel (1998) \\
\hline & C. meini & 2.05 & 2.36 & 2.77 & 101 & 1.56 & 1.80 & 2.09 & 101 & Mein \& Freudenthal (1971b) \\
\hline & C. candirensis & 2.23 & 2.34 & 2.45 & 12 & 2.58 & 1.66 & 1.75 & 12 & Rummel (1998) \\
\hline
\end{tabular}


(López-Guerrero et al. 2008). Nevertheless, De Bruijn et al. (1993) remark that H. lavocati presents some morphological affinities with the representatives from Anatolia (not specifying which ones) and they suggest that it could be related with a late migration from Asia Minor into Europe during the late Aragonian.

As it is described above, local biozone G3 reports the higher number of species of Cricetodontini. This increase has been described, not only for this tribe, but also for large mammals such as ursids (Abella et al. 2011) and ruminants (Sánchez \& Morales 2006, 2008; DeMiguel et al. 2011). The latter ones also reflect a dietary shift towards less abrasive diets (DeMiguel et al. 2011). Many authors argued that all this changes in the faunal assemblages had been related with an increase of humidity (Van der Meulen \& Daams 1992, Daams et al. 1999b, Alcalá et al. 2000, Álvarez-Sierra et al. 2003, DeMiguel et al. 2011) and more diverse vegetation during the G3 (DeMiguel et al. 2011). In Addition, the occurrence of $C$. nievei sp. nov. in TOR3A is coincident with the re-appearance of beavers which supposed the presence of steady water courses (Alcalá et al. 2000, López-Guerrero et al. 2007) agreeing with the proposed increase of humidity. The new environmental conditions established in Calatayud-Daroca Basin seem to be very similar to those from the Vallès-Penedès Basin and Southern France. The implication of these changes in the evolution of Cricetodontini has to be evaluated in the future.

The present work has allowed us to increase the knowledge of the species of Cricetodontini during their maximum diversification interval, as well as to precise their stratigraphical and geographical distribution. Nevertheless, some aspects about the systematics and phylogeny of Cricetodontini remain to be solved; especially regarding those species from the late Aragonian. Indeed, the performance of a cladistic analysis, which is in process, should help us to precise the phylogenetic relationships and evolution of this group.

\section{Acknowledgements}

All co-authors of this manuscript have been equally involved in different stages of the study, including fieldwork, sample preparation, morphometrical analysis and prepared the manuscript. We are very grateful to A.R. Gómez Cano (UCM, Madrid, Spain), R. López-Antoñanzas (MNCN-CSIC, Madrid, Spain), O. Maridet (Naturhistorisches Museum, Vienna, Austria) for providing some essential literature and their useful comments and to J. Prieto (LMU-BSPG, Munich, and HEP, Tübingen, Germany) for his comments on preliminary version of the manuscript. We thank to the editor Š. Doležalová, as well as to the referees, J. Hír and O. Maridet, for their comments, which substantially improved the original manuscript. We also extend our gratitude to L.W. van den Hoek Ostende (NBC, Leiden, The Netherlands), W. Wessels (Utrecht University, Utrecht, The Netherlands), G. Rößner
(BSPG-LMU Munich, Germany) and L. Costeur (MHNB, Basle, Switzerland) for letting us to study the collections under their care. János Hír (Pásztó Múzeum, Pásztó, Hungary) and C. Sesé (MNCN-CSIC, Madrid, Spain) are greatly acknowledged for their kind comments and for let us to check out the material of C. klariankae and H. aguirrei, respectively. We acknowledge the advices of M. Arbalejo Llanes about the rules of Latin grammar to name the new species. We would like to highlight the work of all the colleagues and students who participated in the fieldwork and prepare the material for many years. The Spanish MICINN/MINECO projects CGL2004-02094/BTE, CGL2007-65208, CGL2008-04200/BTE; CGL2011-28877 supports this study. PL-G acknowledges a UCM Predoctoral contract and a "Martin-Fellowship" at the NBC. IG-P holds a JAE-Doc contract (CSIC program "Junta para la Ampliación de Estudios") co-funded by the European Social Fund and acknowledges financial support of the MINECO project CGL2010-21672. This work is a contribution by the Research group UCM-910607 "Evolution of Cenozoic Mammals and Continental Palaeoenvironments".

\section{References}

Abella, J., Montoya, P. \& Morales, J. 2011. A new species of Agriarctos (Ailuropodinae, Ursidae, Carnivora) in the locality of Nombrevilla 2 (Zaragoza, Spain). Estudios Geológicos 67, 187-191. DOI 10.3989/egeol.40714.182

Aguilar, J.P. 1982. Contributions à l'étude des Micromammifères du gisement Miocène supérieur de Montredon (Hérault) 2. les rongeurs. Palaeovertebrata 12, 75-140.

Aguilar, J.P., Calvet, M. \& Michaux, J. 1994. Les rongeurs de Castelnou 6 (Pyrénées-orientales, France) et les corrélations entre faunes ibériques et françaises au Miocène moyen. Neues Jahrbuch für Geologie und Paläontologie, Abhandlungen 192, 109-131.

Aguilar, J.P., Michaux, J. \& LaZZARI, V. 2007. Lo Fournas 16-M (Miocène supérieur) et Lo Fournas 16-P (Pliocène moyen), deux nouvelles localités karstiques à Baixas, Sud de la France Partie II - Nouvelles espèces de rongeurs, listes fauniques et remarque sur l'utilisation biochronologique des faunes karstiques. Géologie de la France 1, 63-81.

Agustí, J. 1980. La associacion de Hispanomys y Cricetodon (Rodentia, Mammalia) en el Mioceno superior del VallèsPenedès (Cataluña, España). Acta Geologica Hispanica 15, $51-60$.

Agustí, J. 1982. Tendencias evolutivas de la línea CricetodonRuscinomys (Rodentia, Mammalia) en la Península Ibérica. Acta Geologica Hispanica 17, 103-111.

Agustí, J. 1986. Nouvelles espèces de cricetides vicariantes dans le Turolien moyen de Fortuna (Prov. Murcia, Espagne). Geobios 19, 5-11. DOI 10.1016/S0016-6995(86)80032-8

Agustí, J., Casanovas-Vilar, I. \& Furió, M. 2005. Rodents, insectivores and chiropterans (Mammalia) from the late Aragonian of Can Missert (middle Miocene, Vallès-Penedès Basin, Spain). Geobios 38, 575-583.

DOI 10.1016/j.geobios.2003.11.011

Alcalá, L., Alonso-Zarza, A.M., Álvarez-Sierra, M.A., Azanza, B., Calvo, J.P., Cañaveras, J.C., Dam, J.V., Garcés, M., Krijgsman, W., Van der Meulen, A., PélaezCampomanes, P., Pérez-González, A., Sánchez Moral, S., 
Sancho, R. \& Sanz Rubio, E. 2000. El registro sedimentario y faunístico de las cuencas de Calatayud-Daroca y Teruel: evolución paleoambiental y paleoclimática durante el Neógeno. Revista de la Sociedad Geológica de España 13, 323-343.

ÁlvareZ-Sierra, M.A. 1987. Estudio sistemático y bioestratigráfico de los Eomyidae (Rodentia) del Oligoceno superior y Mioceno inferior español. Scripta Geologica 86, 1-207.

Álvarez-Sierra, M.A., Calvo, J.P., Morales, J., AlonsoZarza, A., Azanza, B., García-Paredes, I., Hernández Fernández, M., Van der Meulen, A.J., Peláez-Campomanes, P., Quiralte, V., Salesa, M.J., Sánchez, I.M. \& Soria, D. 2003. El tránsito Aragoniense-Vallesiense en el área de Daroca-Nombrevilla (Zaragoza, España). Coloquios de Paleontología Volumen Extraordinario 1, 25-33.

Argyropulo, A. I. 1938. On the fauna of Tertiary Cricetidae of the USSR. Comptes Rendus (Doklady) de l'Académie des Sciences de l'URSS 20, 223-226.

Azanza, B., Alonso-Zarza, M.A., Álvarez-Sierra, M.A., Calvo, J.P., Fraile, S., García-Paredes, I., Gómez, E., Hernández Fernández, M., Van der Meulen, A.J., DeMiguel, D., Montoya, P., Morales, J., Murelaga, X., PeláezCampomanes, P., Perez, B., Quiralte, V., Salesa, M.J., Sánchez Marco, A. \& Soria, D. 2004. Los yacimientos de vertebrados continentales del Aragoniense superior (Mioceno medio) de Toril, Cuenca de Calatayud-Daroca. Geo-Temas 6 , 271-274.

Baudelot, S. 1972. Etude des Chiroptères, Insectivores et Rongeurs du Miocène de Sansan (Gers). 364 pp. Ph.D. thesis, Université Paul Sabatier, Toulouse, France.

CASANOVAS-VILAR, I. 2007. Ecogeographical stability and climate forcing in the Late Miocene (Vallesian) rodent record of Spain. Palaeogeography, Palaeoclimatology, Palaeoecology 248, 169-189. DOI 10.1016/j.palaeo.2006.12.002

DaAms, R., Alcalá, L., Álvarez-Sierra, M.A., Azanza, B., Van Dam, J.A., Van der Meulen, A.J., Morales, J., Nieto, M., Peláez-Campomanes, P. \& Soria, D. 1998. A stratigraphical framework for Miocene (MN4-MN13) continental sediments of Central Spain. Comptes Rendus de l'Academie des Sciences, Séries de la terre et des planètes 327, 625-631.

DaAms, R. \& Freudenthal, M. 1981. Aragonian: the stage concept versus Neogene mammal zones. Scripta Geologica 62, $1-17$.

DaAms, R. \& Freudenthal, M. 1988. Synopsis of the Dutch-Spanish collaboration program in the Neogene of the Calatayud-Teruel basin. Scripta Geologica Special Issue 1, 3-18.

DaAms, R. \& Van der Meulen, A.J. 1984. Paleoenvironmental and paleoclimatic interpretation of micromammal faunal successions in the upper Oligocene and Miocene of north central Spain, 241-257. In Meulenkamp, J. (ed.) Paleoenvironnements continentaux en Méditerrannée au Néogène et évolution paléoclimatique, Paleobiologie Continentale 14.

DaAms, R., Van der Meulen, A.J., Álvarez-Sierra, M.A., Peláez-Campomanes, P., Calvo, J.P., Alonso-Zarza, M.A. \& Krijgsman, W. 1999b. Stratigraphy and sedimentology of the Aragonian (Early to Middle Miocene) in its type area (NorthCentral Spain). Newsletters on Stratigraphy 37, 103-139.

DaAms, R., Van der Meulen, A.J., Álvarez-Sierra, M.A., Peláez-Campomanes, P. \& Krijgsman, W. 1999a. Aragonian stratigraphy reconsidered, and a re-evaluation of the middle
Miocene mammal biochronology in Europe. Earth and Planetary Science Letters 165, 287-294.

DOI 10.1016/S0012-821X(98)00273-8

Daams, R., Van der Meulen, A.J., Peláez-Campomanes, P. \& ÁlvareZ-Sierra, M.A. 1999c. Trends in rodent assemblages from the Aragonian (Early Middle Miocene) of the Calatayud-Daroca Basin (Aragón, Spain), 127-139. In Agustí, J., Rook, L. \& Andrews, P. (eds) Hominoid evolution and climate change in Europe. 1 The evolution of Neogene terrestrial ecosystems in Europe. Cambridge University Press, Cambridge.

De Bruijn, H. 1976. Vallesian and Turolian rodents from Biotia, Attica and Rhodes (Greece). Proceedings of the Koninklijke Nederlandse Akademie van Wetenshappen, Series B 79, 361-384.

De Bruijn, H., DaAms, R., Daxner-Höck, G., Fahlbusch, V., Ginsburg, L., Mein, P. \& Morales, J. 1992. Report of the RCMNS working group on fossil mammals, Reisensburg 1990. Newsletters of Stratigraphy 26, 65-118.

De Bruijn, H., Fahlbusch, V., Saraç, G. \& Ünay, E. 1993. Early Miocene rodent faunas from the eastern Mediterranean area. 3. The genera Deperetomys and Cricetodon with a discussion of the evolutionary history of the Cricetodontini. Proceedings of the Koninklijke Nederlandse Akademie van Wetenschappen, Series B 96, 151-216.

De Bruisn, H. \& ÜNAY, E. 1996. On the evolutionary history of the Cricetodontini from Europe and Asia Minor and its bearing on the reconstruction of migrations and the continental biotope during the Neogene, 227-234. In BERNOR, R.L., Fahlbusch, V. \& Mittmann, H.W. (eds) The evolution of western eurasian Neogene mammal faunas. Columbia University Press, New York.

DeMiguel, D., Azanza, B. \& Morales, J. 2011. Paleoenvironments and paleoclimate of the Middle Miocene of central Spain: A reconstruction from dental wear of ruminants. Palaeogeography, Palaeoclimatology, Palaeoecology 302, 452-463. DOI 10.1016/j.palaeo.2011.02.005

Fischer vON WALDheIM, G. 1817. Adversaria zoologica. Mémoires de la Société Impériale des Naturalistes de Moscou 5, 357-472.

Freudenthal, M. 1963. Entwicklungsstufen der miozänen Cricetodontinae (Mam. Rod.) Mittelspaniens und ihre stratigraphische Bedeutung. Beaufortia 10, 51-157.

Freudenthal, M. 1966. On mammalian fauna of Hipparion-Beds in Calatayud-Teruel Basin (Prov Zaragoza Spain). Ia. Part I. Genera Cricetodon and Ruscinomys (Rodentia). Proceedings of the Koninklijke Nederlandse Akademie van Weteschappen, Series B 69, 298-317.

Garcés, M., Krijgsman, W., Peláez-Campomanes, P., ÁlvarezSierra, M.A. \& DaAms, R. 2003. Hipparion dispersal in Europe: magnetostratigraphic constraints from the Daroca area (Spain). Coloquios de Paleontología Volumen Extraordinario 1, 171-178.

García-Paredes, I. 2006. Patrones evolutivos de los Gliridae (Rodentia, Mammalia) del Mioceno inferior y medio del área tipo del Aragoniense (Cuenca de Calatayud-Montalbán). 676 pp. Ph.D. thesis, Universidad Complutense de Madrid, Madrid, España.

García-Paredes, I., Peláez-Campomanes, P. \& Álvarez-Sierra, M.A. 2009. Gliridae (Rodentia, Mammalia) with a simple den- 
tal pattern: a new genus and new species from the European Early and Middle Miocene. Zoological Journal of the Linnean Society 157, 622-652.

DOI 10.1111/j.1096-3642.2009.00527.x

García-Paredes, I., Peláez-Campomanes, P. \& Álvarez-Sierra, M.A. 2010. Microdyromys remmerti, sp. nov., a new Gliridae (Rodentia, Mammalia) from the Aragonian type area (Miocene, Calatayud-Montalbán Basin, Spain). Journal of Vertebrate Paleontology 30, 1594-1609.

DOI 10.1080/02724634.2010.501453

Hartenberger, J.L. 1965. Les Cricetidae (Rod.) de Can Llobateres (Néogène d'Espagne). Bulletin de la Société Géologique de France 7, 487-498.

Hernández Fernández, M., Cárdaba, J.A., Cuevas-González, J., Fesharaki, O., Salesa, M.J., Corrales, B., Domingo, L., Elez, J., López Guerrero, P., Sala-Burgos, N., Morales, J. \& López Martínez, N. 2006. Los yacimientos de vertebrados del Mioceno medio de Somosaguas (Pozuelo de Alarcón, Madrid): implicaciones paleoambientales y paleoclimáticas. Estudios Geológicos 62, 263-294. DOI 10.3989/egeol.0662126

Hilgen, F.J., LouRENS, L.J. \& VAN DAM, J.A. 2012. The Neogene Period, 923-978. In Gradstein, F.M., OGG, J.G. \& SchmitZ, J.G. (eds) Geologic Time Scale 2012. Cambridge University Press, Cambridge.

Hír, J. 2007. Cricetodon klariankae n. sp. (Cricetodontini, Rodentia) from Felsóltárkány-Fenémet (Northern Hungary). Fragmenta Palaeontologica Hungarica 24-25, 16-24.

HoPKINS, M.J. \& LIDGARD, S. 2012. Evolutionary mode routinely varies among morphological traits within fossil species lineages. Proceedings of the National Academy of Sciences of the United States of America 109, 20520-20525. DOI 10.1073/pnas.1209901109

KäLIN, D. \& KemPF, O. 2009. High-resolution stratigraphy from the continental record of the Middle Miocene Northern Alpine Foreland Basin of Switzerland. Neues Jahrbuch für Geologie und Paläontologie, Abhandlungen 254, 1177-235. DOI 10.1127/0077-7749/2009/0010

Kordos, L. 1986. Upper Miocene hamsters (Cricetidae, Mammalia) of Hasznos and Szentendre. Magyar Allami Földtani Intézet Jelentése az 1984, 523-553.

Klein Hofmeijer, G. \& De Bruijn, H. 1988. The mammals from the Lower Miocene of Aliveri (Island of Evia, Greece). Part 8: The Cricetidae. Proceedings of the Koninklijke Nederlandse Akademie van Wetenshappen, Series B 91, 185-204.

LARTET, E. 1851. Notice sur la colline de Sansan, suivie d'une récapitulation des diverses espèces d'animaux vertébrés fossiles, trouvés soit à Sansan, soint dans d'autres gisements du terrain tertiaire miocène dans le Bassin Sous-Pyrénéen. 41 pp. J.A. Portes, Auch.

López-Antoñanzas, R. \& Mein, P. 2009. First detailed description of Hispanomys bijugatus Mein \& Freudenthal, 1971 (Rodentia, Cricetodontinae) from the Upper Aragonian of La Grive-Saint Alban (France): Biostratigraphical implications. Geobios 42, 783-796. DOI 10.1016/j.geobios.2009.04.002

López-Antoñanzas, R. \& Mein, P. 2011. First detailed description of Hispanomys decedens (Rodentia) from the Middle Miocene of La Grive-Saint Alban (France). Swiss Journal of Geosciences 104, 345-353. DOI 10.1007/s00015-011-0066-0

López-Antoñanzas, R., Peláez-Campomanes, P., ÁlvarezSierra, M.A. \& García-Paredes, I. 2010. New species of
Hispanomys (Rodentia, Cricetodontinae) from the Upper Miocene of Batallones (Madrid, Spain). Zoological Journal of the Linnean Society 160, 725-747.

DOI 10.1111/j.1096-3642.2010.00618.x

López-Guerrero, P., Álvarez-Sierra, M.A., García-Paredes, I., López-AntoÑanzas, R. \& Oliver, A. 2009. Cricetodontini (Rodentia, Mammalia) from the Upper Aragonian and Lower Vallesian of the Toril-Nombrevilla Section (Middle and Upper Miocene, Calatayud-Daroca Basin, Zaragoza, Spain). Journal of Vertebrate Paleontology, supplement to volume 29, $161 \mathrm{~A}$.

López-Guerrero, P., Álvarez-Sierra, M.A., López-Antoñanzas, R., Oliver Pérez, A. \& Peláez-Campomanes, P. 2008. Cricetodontini Cricetidae, Rodentia) del Aragoniense superior (Mioceno medio) de Nombrevilla 2 (Zaragoza, España). Palaeontologica Nova 8, 259-271.

López-Guerrero, P., García-Paredes, I. \& Álvarez-Sierra, M.A. 2013. Revision of Cricetodon soriae (Rodentia Mammalia), new data from the middle Aragonian (Middle Miocene) of the Calatayud-Daroca Basin (Zaragoza, Spain). Journal of Vertebrate Paleontology 33, 169-184.

DOI 10.1080/02724634.2012.716112

López-Guerrero, P., García-Paredes, I., Van den Hoek Ostende, L.W., Van Dam, J.A., Álvarez-Sierra, M.A., Hernández-Ballarín, V., Van der Meulen, A.J., Oliver, A. \& Peláez-Campomanes, P. 2011. Cañada: a new micromammal succession from the lower Vallesian and Turolian of the Daroca area (Calatayud-Montalbán basin, Spain). Estudios Geológicos 67, 443-453. DOI 10.3989/egeol.40563.201

López-Guerrero, P., Oliver Pérez, A., Álvarez-Sierra, M.A., García-Paredes, I \& Peláez-Campomanes, P. 2007. El registro de los Castoridae (Rodentia, Mammalia) del Aragoniense y Vallesiense (Mioceno Medio y Superior) de las cuencas centrales españolas, 118-119. In BrAGA, J.C., CHECA, A. \& Company, M. (eds) XXIII Jornadas de la Sociedad Española de Paleontología (Caravaca de la Cruz 3-6 de Octubre de 2007). Libro de resúmenes. Instituto Geológico y Minero de España \& Universidad de Granada, Granada.

López-Martínez, N. 1997. Lignées évolutives, formes intermédiaires et évolution en mosaïque: exemple des lagomorphes européens, 105-120. In Aguilar, J.P., Legendre, S. \& Michaux, J. (eds) Congrès BiochroM '97. Mémoires et Travaux EPHE, Institut Montpellier, Montpellier.

López-Martínez, N., Sesé Benito, C. \& Sánz-García, J.L. 1977. La microfauna (Rod., Insect., Lagomorph y Reptilia) de las fisuras del Mioceno medio de Escobosa de Calatañazor (Soria, España). Acta Geologica Hispanica 12, 47-73.

Maridet, O. \& Sen, S. 2012. Les Cricetidae du gisement de Sansan, 29-65. In Peigne, S. \& Sen, S. (eds) Mammifères de Sansan. Mémoires du Muséum national d'histoire naturelle 203.

Mein, P. \& Freudenthal, M. 1971a. Une nouvelle classification des Cricetidae (Mam.Rod.) du Tertiaire d'Europe. Scripta Geologica 2, 1-37.

Mein, P. \& Freudenthal, M. 1971b. Les Cricetidae (Mammalia, Rodentia) du Néogène Moyen de Vieux-Collonges. Part 1. Le genre Cricetodon Lartet, 1851. Scripta Geologica 5, 1-51.

Oliver, A., López-Guerrero, P., García-Paredes, I., ÁlvarezSierra, M.A. \& Peláez-Campomanes, P. 2009. Evolution of Megacricetodon tooth pattern through geometric morpho- 
metric analysis. Journal of Vertebrate Paleontology supplement to volume $29,158 \mathrm{~A}$.

Oliver, A. \& Peláez-Campomanes, P. 2013. Megacricetodon vandermeuleni, sp. nov. (Rodentia, Mammalia), from the Spanish Miocene: a new evolutionary framework for Megacricetodon. Journal of Vertebrate Paleontology 33, 943-955. DOI 10.1080/02724634.2013.743896

Peláez-Campomanes, P. 2001. Revision of the Aragonian (Miocene) Atlantoxerus (Sciuridae). Journal of Paleontology 75, $418-426$.

DOI 10.1666/0022-3360(2001)075<0418:ROTAMA >2.0.CO;2

Prieto, J., BöHme, M. \& Gross, M. 2010. The cricetid rodents from Gratkorn (Austria, Styria): a benchmark locality for the continental Sarmatian sensu stricto (late Middle Miocene) in the Central Paratethys. Geologica Carpathica 61, 419-436. DOI 10.2478/v10096-010-0025-0

QiU, Z.D. 2010. Cricetid Rodents from the early Miocene Xiacaowan formation, sihong, Jiangsu. Vertebrata PalAsiatica 48, $27-47$.

Rummel, M. 1995. Cricetodon bolligeri n. sp. ein neuer Cricetide aus dem Obermiozän von Petersbuch bei Eichstätt. Mitteilungen der Bayerischen Staatssammlung für Paläontologie und historische Geologie 35, 109-123.

Rummel, M. 1999. Tribe Cricetodontini, 359-364. In RÖßNER, G. \& Heisig, K. (eds) The Miocene land mammals of Europe. Verlag Dr. Friedrich Pfeil, München.

Rummel, M. 2000. Miocene Cricetodontini from Petersbuch near Eichstaett. The genus Cricetodon Lartet 1851. Senckenbergiana lethaea 80, 149-171.

Rummel, M. 2001. Ein neuer Cricetodon aus dem Miozän von Petersbuch bei Eichstätt. Stuttgarter Beiträge zur Naturkunde, Series B 311, 1-6.

Rummel, M. \& Kälin, D. 2003. Die Gattung Cricetodon (Mammalia, Rodentia) aus den Mettelmiozän der Schweizer Molasse. Zitteliana 43, 123-141.

SÁNCHEZ, I.M. \& MoRALES, J. 2006. Distribución biocronológica de los Moschidae (Mammalia, Ruminantia) en España. Estudios Geológicos 62, 533-543. DOI 10.3989/egeol.0662153

SÁNCHEZ, I.M. \& MoRALES, J. 2008. Micromeryx azanzae sp. nov. (Ruminantia: Moschidae) from the middle-upper Miocene of Spain, and the first description of the cranium of Micromeryx. Journal of Vertebrate Paleontology 28, 873-885. DOI 10.1671/0272-4634(2008)28[873:MASNRM]2.0.CO;2

Schaub, S. 1925. Die hamsterartigen Nagetiere des Tertiärs und ihre lebenden Verwandten. Abhandlungen der Schweizerischen paläontologischen Gesellschaft 45, 1-114.

Sen, S. \& Erbajeva, M.A. 2011. A new species of Gobicricetodon Qiu, 1996 (Mammalia, Rodentia, Cricetidae) from the Middle Miocene of Aya Cave, Lake Baikal. Vertebrata PalAsiatica 49, 257-274.

Sen, S. \& Ünay, E. 1979. Sur quelques Cricetodontini (Rod.) du Miocène moyen d'Anatolie. Proceedings of the Koninklijke Nederlandse Akademie van Wetenshappen, Series B 82, 293-301.

SesÉ Benito, C. 1977. Los cricétidos (Rodentia, Mammalia) de las fisuras del Mioceno Medio de Escobosa de Calatañazor (Soria, España). Trabajos del Neógeno Cuaternario 8, 127-180.

SimPSON, G.G. 1945. The principles of classification and a classi- fication of mammals. Bulletin of the American Museum of Natural History 85, 1-350.

StebBins, G.L. 1983. Mosaic evolution: An integrating principle for the modern synthesis. Experientia 39, 823-834. DOI 10.1007/BF01990398

Stehlin, H.G. \& Schaub, S. 1951. Die Trigonodontie der simplicidentaten Nager. Schweizerische paläontologische Abhandlungen 67, 1-385.

Steininger, F. 1999. Chronostratigraphy, Geochronology and Biochronology of the Miocene 'European Land Mammals Mega-Zones' (ELMMZ) and the Miocene 'Mammal-Zones (MN-Zones)', 9-24. In RößNeR, G. \& Heisig, K. (eds) The Miocene land mammals of Europe. Verlag Dr. Friedrich Pfeil, München.

Tobien, H. 1978. New species of Cricetodontini (Rod. Mam.) from the Miocene of Turkey. Mainzer Geowissenschaftliche Mitteilungen/ Geologisches Landesamt Rheinland-Pfalz 6, 209-219.

ÜNAY, E. 1980. The Cricetodontini (Rod. Mam.) from the Bayraktepe section (Çanakkale, Turkey). Proceedings of the Koninklijke Nederlandse Akademie van Wetenschappen, Series $B$ 83, 399-418.

Ünay, E. \& DE Bruijn, H. 1984. On some Neogene Rodent assemblages from both sides of the Dardanelles, Turkey. Newsletter of Stratigraphy 13, 119-132.

Van Dam, J.A., Abdul-Aziz, H., Álvarez-Sierra, M.A., Hilgen, F.J., Van den Hoek Ostende, L.W., Lourens, L., Mein, P., Van der Meulen, A.J. \& Peláez-Campomanes, P. 2006. Long-period astronomical forcing of mammal turnover. $\mathrm{Na}$ ture 443, 687-691. DOI 10.1038/nature05163

VAN DeR Meulen, A.J. \& DAAMs, R. 1992. Evolution of early-middle Miocene rodent faunas in relation to long-term palaeoenvironmental changes. Palaeogeography, Palaeoclimatology, Palaeoecology 93, 227-253.

DOI 10.1016/0031-0182(92)90099-Q

Van der Meulen, A.J., García-Paredes, I., Álvarez-Sierra, M.A., Van den Hoek Ostende, L.W., Hordijk, K., LóPezGuerrero, P., Hernández-Ballarín, V. \& Peláez-CampoMANES, P. 2011. Biostratigraphy or biochronology? Lessons from the Early and Middle Miocene small mammal events in Europe. Geobios 44, 309-321. DOI 10.1016/j.geobios.2010.11.004

Van der Meulen, A.J., García-Paredes, I., Álvarez-Sierra, M.A., Van den Hoek Ostende, L.W., HordijK, K., Oliver, A. \& Peláez-Campomanes, P. 2012. Updated Aragonian biostratigraphy: Small Mammal distribution and its implications for the Miocene European Chronology. Geologica Acta 10, 1-24.

Van der Meulen, A.J., Peláez-Campomanes, P. \& DaAms, R. 2003. Revision of medium-sized Cricetidae from the Miocene of the Daroca-Villafeliche area in the Calatayud-Teruel basin (Zaragoza, Spain). Coloquios de Paleontología Volumen Extraordinario 1, 385-441.

WEERD, A. VAN DE 1976. Rodent faunas of the Mio-Pliocene continental sediments of the Teruel-Alfambra region, Spain. Utrecht micropaleontological bulletins, University of Utrecht 1976, 1-218.

Wu, W.Y., Meng, J., Ye, J., Ni, X.J., BI, S.D. \& WeI, Y.P. 2009. The Miocene mammals from Dinshanyanchi Formation of North Junggar Basin, Xinjiang. Vertebrata PalAsiatica 47, 208-233. 